\title{
Depositional setting and limiting factors of early Late Cretaceous glaucony formation: implications from Cenomanian glauconitic strata (Elbtal Group, Germany)
}

\author{
Markus Wilmsen $^{1} \cdot$ Udita Bansal $^{1}$
}

Received: 18 December 2020 / Accepted: 7 April 2021 / Published online: 14 June 2021

(c) The Author(s) 2021

\begin{abstract}
Cenomanian strata of the Elbtal Group (Saxony, eastern Germany) reflect a major global sea-level rise and contain, in certain intervals, a green authigenic clay mineral in abundance. Based on the integrated study of five new core sections, the environmental background and spatio-temporal patterns of these glauconitic strata are reconstructed and some general preconditions allegedly needed for glaucony formation are critically questioned. XRD analyses of green grains extracted from selected samples confirm their glauconitic mineralogy. Based on field observations as well as on the careful evaluation of litho- and microfacies, 12 glauconitc facies types (GFTs), broadly reflecting a proximal-distal gradient, have been identified, containing granular and matrix glaucony of exclusively intrasequential origin. When observed in stratigraphic succession, GFT-1 to GFT-12 commonly occur superimposed in transgressive cycles starting with the glauconitic basal conglomerates, followed up-section by glauconitic sandstones, sandy glauconitites, fine-grained, bioturbated, argillaceous and/ or marly glauconitic sandstones; glauconitic argillaceous marls, glauconitic marlstones, and glauconitic calcareous nodules continue the retrogradational fining-upward trend. The vertical facies succession with upwards decreasing glaucony content demonstrates that the center of production and deposition of glaucony in the Cenomanian of Saxony was the nearshore zone. This time-transgressive glaucony depocenter tracks the regional onlap patterns of the Elbtal Group, shifting southeastwards during the Cenomanian 2nd-order sea-level rise. The substantial development of glaucony in the thick (60 m) uppermost Cenomanian Pennrich Formation, reflecting a tidal, shallow-marine, nearshore siliciclastic depositional system and temporally corresponding to only $\sim 400 \mathrm{kyr}$, shows that glaucony formation occurred under wet, warm-temperate conditions, high accumulation rates and on rather short-term time scales. Our new integrated data thus indicate that environmental factors such as great water depth, cool temperatures, long time scales, and sediment starvation had no impact on early Late Cretaceous glaucony formation in Saxony, suggesting that the determining factors of ancient glaucony may be fundamentally different from recent conditions and revealing certain limitations of the uniformitarian approach.
\end{abstract}

Keywords Lower Upper Cretaceous · Transgression · Glaucony · Stratigraphy · Depositional environments

\section{Introduction}

The sedimentary strata of the Cenomanian Stage record one of the largest sea-level rises of the Mesozoic Era (e.g., Hancock and Kauffman 1979; Haq et al. 1987; Hancock 1989; Robaszynski et al. 1998; Wilmsen 2003; Kuhnt et al.

Markus Wilmsen

markus.wilmsen@senckenberg.de

Udita Bansal

udita.bansal@senckenberg.de

1 Senckenberg Naturhistorische Sammlungen Dresden, Museum für Mineralogie und Geologie, Königsbrücker Landstr. 159, 01109 Dresden, Germany 2009; Haq 2014). Consequently, lower Upper Cretaceous strata often onlap former non-depositional areas, sealing inherited palaeo-topographies and commonly recording a significant up-section deepening of the depositional environment (Wilmsen et al. 2005). In many cases, the sedimentary rocks deposited during this transgressive megacycle contain an authigenic green mineral (presumed glauconite) in 


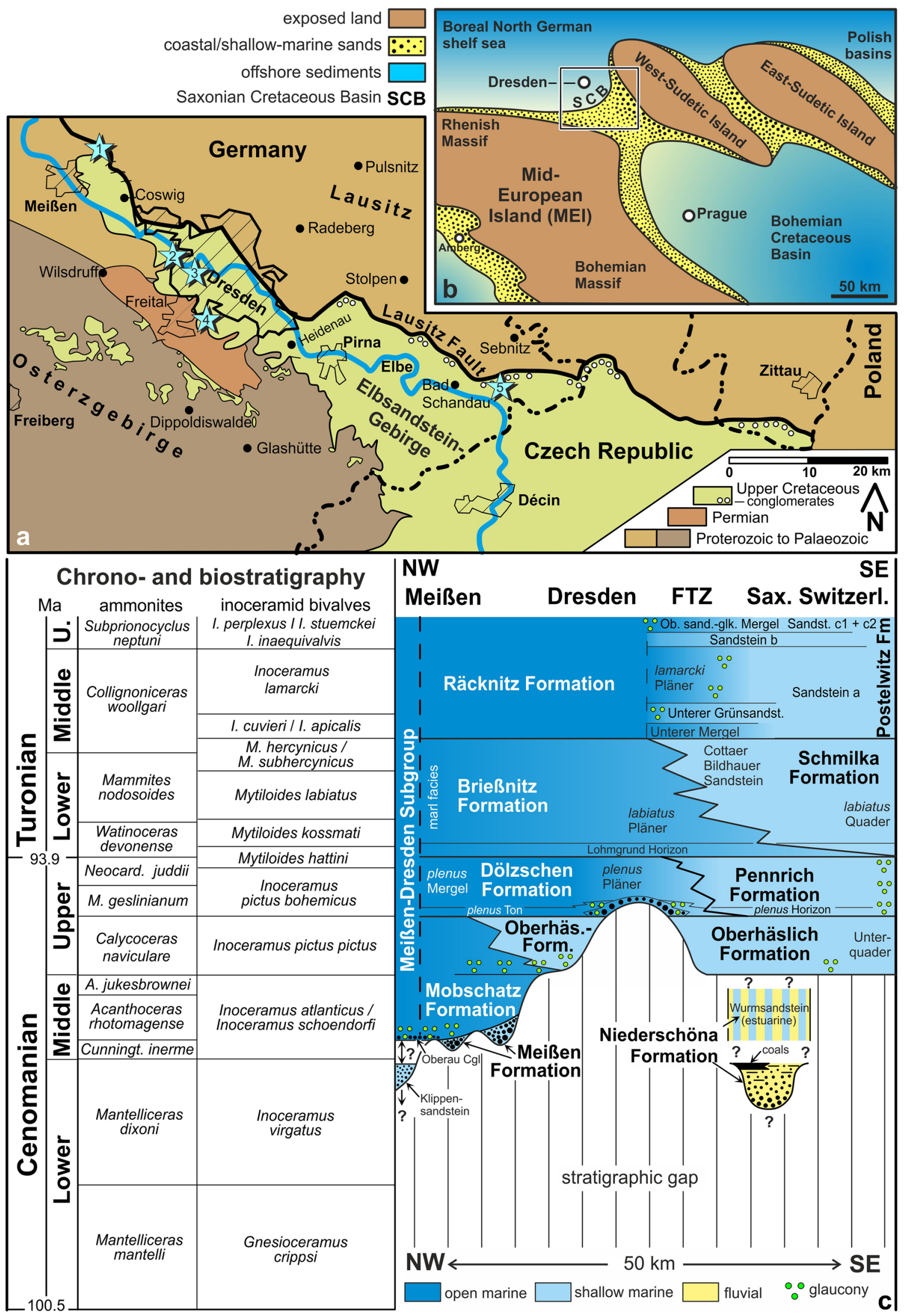


4Fig. 1 Geological and palaeogeographic setting. a Distribution of the Elbtal Group in the area between Meißen and the Czech border, following the course of the river Elbe; the studied sections are indicated by blue asterisks (1: Meißen-Oberau area; 2 : temporary exposure at motorway A4; 3: core section Nossener Brücke; 4: cores HG 6512 and 6513; 5: core Nasser Grund. b Palaeogeographic setting of the Saxonian Cretaceous Basin (SCB). c Chrono-, bio- and lithostratigraphy of the Elbtal Group, supplemented and modified after Wilmsen et al. (2019) and Niebuhr et al. (2020); glaucony occurrences are indicated $(\mathrm{FTZ}=$ Facies transition zone; $\mathrm{U} .=$ Upper $)$. Biostratigraphy: A.=Acanthoceras $; \quad$ Cunningt.$=$ Cunningtoniceras $; \quad I .=$ Inoceramus; M. $=$ Metoicoceras $; \quad M .=$ Mytiloides $; \quad$ Neocard.$=$ Neocardioceras $;$ W. $=$ Watinoceras

abundance, leading to the formation of in part very thick greensand successions (e.g., in the Münsterland Cretaceous Basin of northern Germany; Bärtling 1920; Seibertz 1977; Wildberg 1980; Hiss 1982; Berensmeier et al. 2018a, b). Also in the Saxonian Cretaceous Basin of eastern Germany, transgressive glauconitic strata received early attention (Geinitz 1850) and also have been regionally mapped at the base of the Cretaceous successions in the Meißen-Dresden area (Beck and Hazard 1893; Siegert 1906). However, detailed sedimentological and mineralogical information on these deposits from Saxony is lacking and new data on their regional occurrence and stratigraphic classification have been compiled in recent years. This paper thus concentrates and complements the information on greensand deposits in the Cretaceous of Saxony based on the detailed logging of new Cenomanian sections associated with careful petrographical and mineralogical analyses of glauconitic intervals. Furthermore, some conditional prerequisites allegedly needed for glaucony formation, deeply entrenched in the literature, are critically scrutinized.

\section{Geological setting}

The Lower Cenomanian to Middle Coniacian Elbtal Group, formally defined by Voigt and Tröger in Niebuhr et al. (2007) and recently revised by Niebuhr et al. (2020), comprises marine sandstones and conglomerates, calc-arenites, calcareous siltstones, and silty marlstones (regionally called Pläner), marls and marly limestones as well as continental deposits that occur locally at the base (fluvial gravels, sand- and siltstones and coals of the Lower-Middle Cenomanian Niederschöna Formation). The strata of the Elbtal Group were deposited in a fairly narrow strait between the small West-Sudetic Island in the northeast and the large Mid-European Island in the southwest, widening to the southeast into the much larger Bohemian Cretaceous Basin. To the northwest, the strait opened into the broad northern German Boreal shelf sea (Fig. 1a, b). The fossiliferous character of the strata of the Elbtal Group enabled the development of a precise high-resolution biostratigraphic framework based on inoceramid bivalves and ammonites, facilitating a detailed chronostratigraphic calibration and correlation of the lithostratigraphic units (e.g., Petrascheck 1902; Seifert 1955; Tröger 1967, 1969; Wilmsen and Nagm 2013, 2014; Tröger and Niebuhr 2014; Tröger 2015; Wilmsen et al. 2019; Niebuhr et al. 2020).

The first transgression into the Elbe Zone proceeded from the northwest and reached the Oberau-Meißen area in the Early Cenomanian (Klippensandstein; Fig. 1c; Wilmsen et al. 2019). However, the main onlap phase started with a first major transgression in the early Middle Cenomanian, reflected by the deposition of the lower part of the marly Mobschatz Formation and its local shallow-water equivalent, the Meißen Formation (Wilmsen et al. 2019) as well as the continued backfilling of fluvial valleys with estuarine sediments (bioturbated, so-called "Wurmsandstein" of the upper Niederschöna Formation). The second transgressive pulse characterizes the early Late Cenomanian, causing onlap of nearshore sandstones (Oberhäslich Formation) onto the Osterzgebirge (Voigt 1994; Wilmsen 2017) and far into the area of today's Saxonian Switzerland while in the northwestern Dresden-Meißen area, marly-calcareous offshore deposition (upper Mobschatz Formation) prevailed (Wilmsen et al. 2019). The third and most important transgressive event occurred in the latest Cenomanian, drowning remaining basement uplifts (Voigt et al. 1994, 2006; Wilmsen et al. 2011) and establishing the wide facies belts of an open, grain-size-graded shelf (marly-calcareous offshore deposits of the Dölzschen Formation and sandy nearshore facies of the Pennrich Formation; Niebuhr 2020). The oscillating Cenomanian sea-level rise finally culminated in an earliest Turonian maximum flooding event with the onlap of fine-grained deposits far into the proximal sandy facies zone (Lohmgrund Horizon; see Niebuhr et al. 2020 and Fig. 1c). During the Early and Middle Turonian, the depositional patterns of a grain-size-graded shelf with marly-calcareous offshore deposits (Brießnitz and Räcknitz formations) and a sandy nearshore zone (Schmilka and Postelwitz formations) prevailed (Fig. 1c; see also Voigt 1999).

The Elbtal Group is bordered today in the northeast by the Lusatian Fault at which Neoproterozoic greywackes and Cambrian granitoids have been thrusted onto its upper Palaeozoic and Mesozoic cover (Fig. 1a; see Voigt 2009 and Käßner et al. 2020 for a recent synopsis). Thickness and facies variations suggest that the synsedimentary activity of the Lusatian Fault had an essential influence of the accumulation of the Cretaceous strata from the Middle Turonian onwards (Niebuhr et al. 2020).

\section{Material and methods}

Stratigraphic sections have been logged and sampled in great detail bed-by-bed, applying standard sedimentary and palaeontological field methods (e.g., Goldring 1999; Stow 


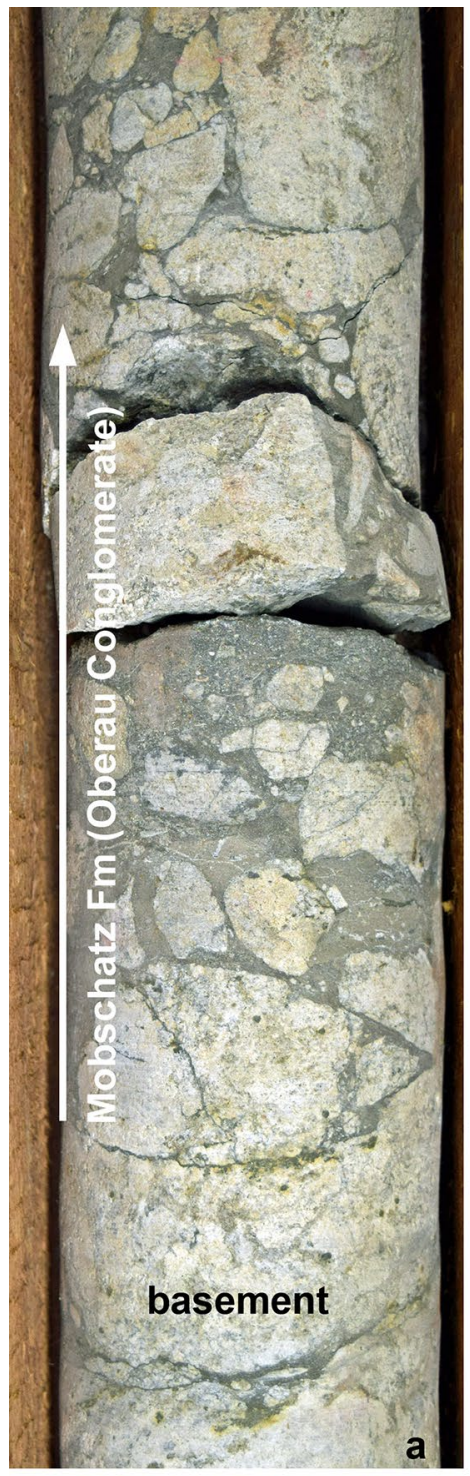

$3+x^{2}+x^{2}+21$ 1. Penmed ph of M $\left.=27^{2}+1\right\}$ det? $x+4$ $(x+2) x^{2}, 2$

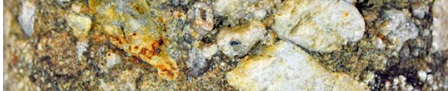

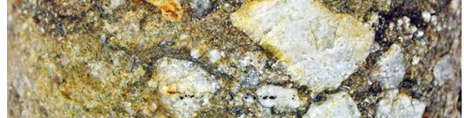
10 ind

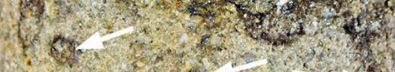
Oberhäșlich Fm b
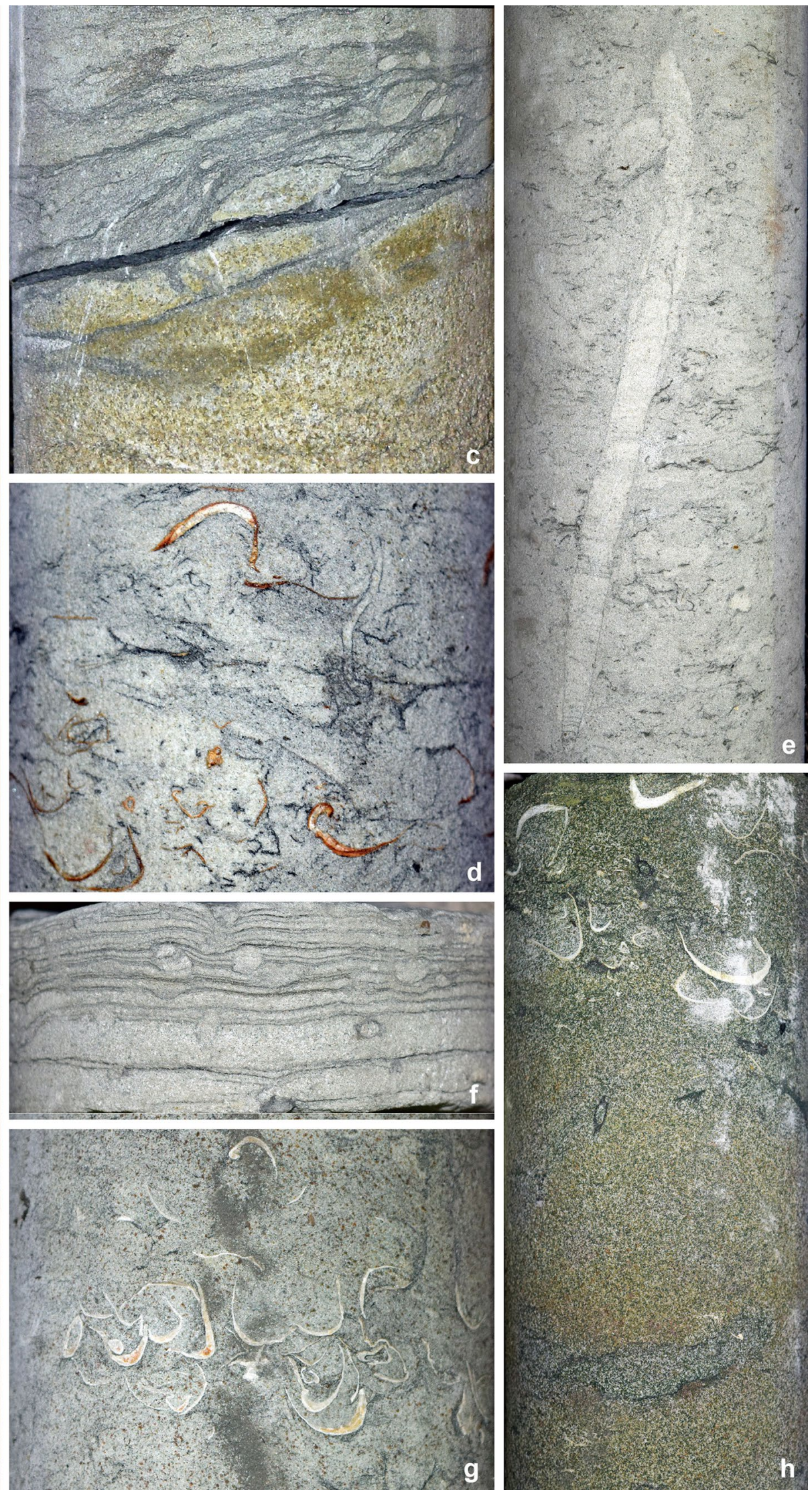
4 Fig. 2 Selected core photos (width of the core segments is $100 \mathrm{~mm}$ each; except a, all images from the Pennrich Formation of core Nasser Grund). a Lower Middle Cenomanian Oberau Conglomerate in the B14 core, forming the basal bed of the Mobschatz Formation. b Mid-Upper Cenomanian basal conglomerate of the Pennrich Formation in the Nasser Grund core at 291.20, unconformably resting on the Oberhäslich Formation below; note down-piping of dark, sandy-glauconitic matrix into the top of the Oberhäslich Formation (arrows). c Sharp contact between brown coarse-grained sandstones and bioturbated, argillaceous fine-grained sandstones at $270.30 \mathrm{~m}$ (top of cycle P1). d Scattered iron-stained oysters shells in bioturbated, fine-grained sandstones at $265 \mathrm{~m}$; note scattered black plant debris. e Bioturbated, fine-grained sandstones at $260 \mathrm{~m}$; note long, subvertical shaft of Ophiomorpha burrow. f Bundled clay seams in bioturbated, medium-grained sandstones at $249.20 \mathrm{~m}$, indicating tidal influences. $\mathrm{g}$ Bioclastic glauconitic sandstones at $238 \mathrm{~m}$ with oyster shell bed; note the convex-down orientation of most shells and partial nesting. h Sandy glauconitite with oyster shell concentration towards the top, forming the uppermost part of cycle P3 at 234.80-235.10 m

2005). 64 thin-sections and four large polished slabs have been prepared with a Logitech preparation line including a LP50 lapping and polishing jig with a PLJ7 lapping jig and a GTS-1 thin-section saw. Thin-sections were studied using a Leica M125 stereo-microscope with a Leica DFC 420 digital camera capturing images in the optical pathway. Carbonate rocks were classified according to Dunham (1962) while sandstone nomenclature follows Dott (1964; see also Pettijohn et al. 1987 and Garzanti 2019 for reviews). The regionally common lithological name "Pläner" refers to generally well-bedded, fine-grained, bioturbated calcareous siltstones to silty calcareous marlstones. For glauconitic strata containing more than $50 \%$ glaucony grains, the term glauconitite (Funk 1971) is applied. In a semi-quantitative approach to estimate visual percentage shares of the included components, we used the comparison charts of Baccelle and Bosellini (1965). The thin-sections are stored in the palaeozoological collections of the Senckenberg Naturhistorische Sammlungen Dresden (SNSD), repository SaK. The cores HG 6512 and 6513 are likewise stored at the SNSD while the Gröbern cores B14 and 2/91 are in the core repository of the TU Bergakademie Freiberg (TUBAF), the core Nossener Brücke is in a repository of the city of Dresden and the core Nasser Grund in the core archive of the Geological Survey of the Federal State of Saxony (LfULG), Freiberg.

For XRD analyses of green grains, powdered samples were scanned from $5^{\circ}$ to $90^{\circ} 2 \theta$ with a step size of $0.01^{\circ}$ and with a scan speed of $0.5 \mathrm{~s} / \mathrm{step}$, using $\mathrm{Cu}-\mathrm{K} \alpha$ radiation in a Bruker D8 ADVANCE diffractometer with LYNXEYE XEDetector based in the Mineralogy Section of the Museum of Mineralogy and Geology, Senckenberg Natural History Collections Dresden, Germany. The software used for measurement and evaluating peaks is DIFFRAC.SUITE v6.5.0 with DIFFRAC.MEASUREMENT and DIFFRAC.EVA. X-ray diffraction peaks were studied to identify the mineral 'glauconite' and associated minerals in the samples. However, according to López-Quirós et al. (2020), glauconite in a strict mineralogical sense is a mica-rich mica-smectite R3 interstratified mineral, with the pure end-member mica also having intrinsic $K$-deficient geochemical characteristics $(K+\sim 0.8 \mathrm{apfu})$ while our XRD analyses do not exclude smectite-poor interstratified $\sim 10 \AA$ glauconite-smectite. Thus, we use the more generic terms glaucony or glauconitic (attributed to nouns such as grains, facies, mineral, etc.) in the context of the green grains studied herein (cf. Odin and Fullagar 1988).

\section{Results}

Five new sections were studied and are described following a NW-SE transect (chapter Measured sections). They are located in the Oberau area northeast of Meißen, in the city of Dresden, on the northeastern margin of the Erzgebirge and in the Saxonian Switzerland (Fig. 1a). Glauconitic strata have been subdivided into facies types (chapter Glauconitic facies types, GFTs) and picked green grains from selected samples have been analyzed for their mineralogy using X-ray diffraction (chapter XRD analyses).

\section{Measured sections}

\section{Gröbern composite section}

The Cenomanian-Lower Turonian succession of the Oberau area is a composite section based on the newly logged core B14 (lowermost part) and the core Gröbern 2/91 (upper part). Both cores were drilled in the Gröbern area in 1991 for subsurface investigation of a planned landfill site. The lowermost part of the core 2/91 including the contact of the Cretaceous strata to the basement is not anymore available and was replaced in the paper of Wilmsen et al. (2019) by an only moderately exposed railway slope cut section ca. one $\mathrm{km}$ to the southwest. However, the B14 core was drilled directly adjacent to core $2 / 91$ and was recently re-discovered in the core archive of the TU Bergakademie Freiberg, forming a much better, fully exposed, indigenous foundation of the Upper Cretaceous in the Oberau area.

The basement rocks at Gröbern consist of an Augengneiss belonging to the large intrusive body of the Carboniferous Meißen Massif. They are overlain in core B14 along a fissured erosion surface by the ca. 0.8-m-thick Oberau Conglomerate consisting of moderately rounded to sub-angular gneiss pebbles and cobbles within a marlyglauconitic matrix (Figs. 2a, 3a). This basal conglomerate of the Mobschatz Formation is followed by $1.6 \mathrm{~m}$ of feldspatic, partly cross-bedded, medium- to coarse-grained glauconitic sandstones to sandy glauconitites, overlain by weakly glauconitic argillaceous marls. A sample from 

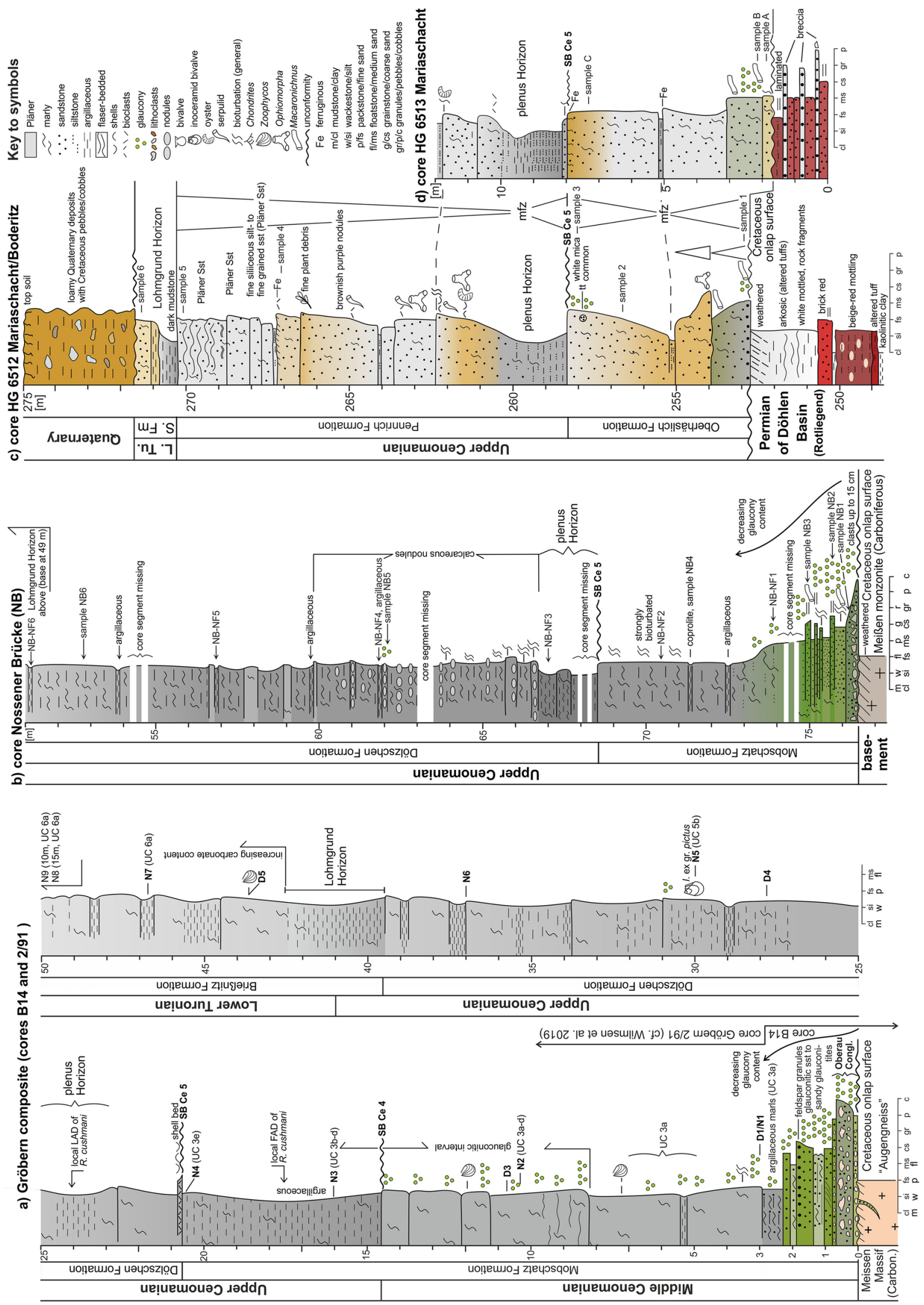
4Fig. 3 Detailed logs of measured sections (see Fig. 1a for localities). a Gröbern composite core section. b Core section Nossener Brücke. c Core section HG 6512 Mariaschacht/Boderitz. d Core section HG 6513 Mariaschacht. $L$. Tu. Lower Turonian, $m f z$ maximum flooding zone, $S B$ sequence boundary, $S$. Fm Schmilka Formation

this level contained $C$. sculptus and G. theta, i.e., calcareous nannofossils of the biozones UC2c to UC3a (uppermost Lower to lower Middle Cenomanian) sensu Burnett (1998). Up-section, the succession of core 2/91 continues with bioturbated, fine-grained silty, glaucony-bearing calcareous strata for about $12 \mathrm{~m}$ (Fig. 3a); calcareous nannofossils and stable carbon isotopes date this part as Middle Cenomanian (Wilmsen et al. 2019). Above an abrupt facies change at $14.6 \mathrm{~m}$, argillaceous marls form the upper Mobschatz Formation (lower Upper Cenomanian). At a shell bed at $20.6 \mathrm{~m}$, the mid- to uppermost Cenomanian Dölzschen Formation starts, ranging up to the base of the argillaceous Lohmgrund Horizon at $39.6 \mathrm{~m}$ that is forming the base of the overlying Brießnitz Formation and contains the Cenomanian-Turonian boundary (Wilmsen et al. 2019). The Dölzschen Formation consists of a monotonous intercalation of argillaceous marls and calcareous marlstones with rare macrofossils, occasionally containing a little glaucony. Above the Lohmgrund Horizon, carbonate contents start to rise and the Lower Turonian Brießnitz Formations comprises calcareous bioturbated marlstones (Fig. 3a).

\section{Core section Nossener Brücke}

The basement rocks of the Nossener Brücke section consist of a Carboniferous monzonite belonging to Meißen Massif (Fig. 3b). They are overlain by the ca. 8-m-thick lower Upper Cenomanian Mobschatz Formation. At the base of the Mobschatz Formation, a ca. 0.2-m-thick conglomerate bed consisting of angular to sub-rounded pebbles of weathered basement occurs, showing a marly-glauconitic matrix (Fig. 3b). The basal conglomerate gradationally passes into a glaucony-rich, ca. 1.2-m-thick interval of bioturbated sandstones containing numerous large Macaronichnus burrows and intercalated parallel-laminated, sharp-based glauconitic sandstones. An argillaceous marl bed at $72.7 \mathrm{~m}$ marks the transition from glauconitic sandstones and glauconitic marlstones to strongly-bioturbated, non-glauconitic marls and Pläner forming the middle and upper part of the Mobschatz Formation. A coprolite bed at $71.3 \mathrm{~m}$ occurs within this interval. At $69.5 \mathrm{~m}$, a ca. 2-m-thick argillaceous marl unit forms the basal plenus Horizon of the upper Upper Cenomanian Dölzschen Formation, followed by strongly bioturbated argillaceous marlstones characterized by abundant, in part weakly glauconitic calcareous nodules in the lower part (up to ca. $60 \mathrm{~m}$ ). Argillaceous layers occur at different levels (62 $\mathrm{m}, 60 \mathrm{~m}$ and $53.9 \mathrm{~m}$ ), the deepest associated with rare glaucony. Sample NB-NF3 at $67 \mathrm{~m}$ contains a rather poor calcareous nannofossil assemblage with ca. 10 species including A. albianus; it is thus not younger than UC5a sensu Burnett (1998), i.e. upper Metoicoceras geslinianum ammonite Zone (mid-Late Cenomanian). Up-section, the Dölzschen Formation passes conformably into the lowermost Turonian Lohmgrund Horizon at $49 \mathrm{~m}$.

A few kilometers to the northwest of the Nossener Brücke core section, the glauconitic strata at the base of the Dölzschen Formation have been exposed in 2004-05 during construction at the motorway A4 exit Dresden-Altstadt. The observed lithofacies includes hummocky-cross-bedded, graded glauconitic sandstones and bioturbated glauconitic sandstones, similar to what has been logged between 76.10 and $74.80 \mathrm{~m}$ at Nossener Brücke.

\section{Cores HG 6512 and 6513}

The substrate at core sections HG 6512 and 6513 (Fig. 3c, d) consist of Permian rocks of the Döhlen Basin. These volcaniclastic rocks comprise kaolinitic clays, arkosic altered tuffs with beige-red mottling, brick-red sandstones, and grey breccia layers. The pre-Cretaceous substrate is overlain by lower Upper Cenomanian Oberhäslich Formation in both the sections that are only ca. $500 \mathrm{~m}$ apart. The ca. $5.5 \mathrm{~m}$ thick Oberhäslich Formation in core HG 6512 predominantly consists of weakly bioturbated sandstones (Fig. 3c). The sandstones are glauconitic at the base with abundant large Macaronichnus burrows followed by a coarse-grained sandstone that fines upwards into a ca. 0.2-m thick fine-grained siltstone bed at $255 \mathrm{~m}$. The upper part of the formation shows a coarsening-upward trend and contains white mica. In section HG 6513, the ca. $6.2 \mathrm{~m}$ thick Oberhäslich Formation exhibits similar lithological characteristics with Macaronichnus-bioturbated glauconitic sandstones at the base followed by grey, medium-grained sandstones above. A fine-grained siltstone bed at $5 \mathrm{~m}$ can be used to correlate both sections. The top surface of the Oberhäslich Formation is sharp and bioturbated, and unconformably overlain by ca. 2-m-thick fine argillaceous siltstones of the plenus Horizon at the bases of the upper Upper Cenomanian Pennrich Formation (Fig. 3c, d). The Pennrich Formation, of which only the lower $4 \mathrm{~m}$ are preserved in the HG 6513 core, essentially comprises ca. 6.3 $\mathrm{m}$ of medium-grained, weakly bioturbated, non-glauconitic sandstones rich in Ophiomorpha burrows that also contain a few macrofossils such as oysters and serpulids as well as fine plant debris. The top of the lower sandstone unit is marked by bioclasts and ferruginous staining. Above a siltstone bed, ca. $3.6 \mathrm{~m}$ of wavy laminated, slightly bioturbated siliceous sandstones form the upper part of the Pennrich Formation. A dark mudstone bed starting at $269.8 \mathrm{~m}$ belongs to the overlying Lohmgrund Horizon of the Lower Turonian Schmilka 


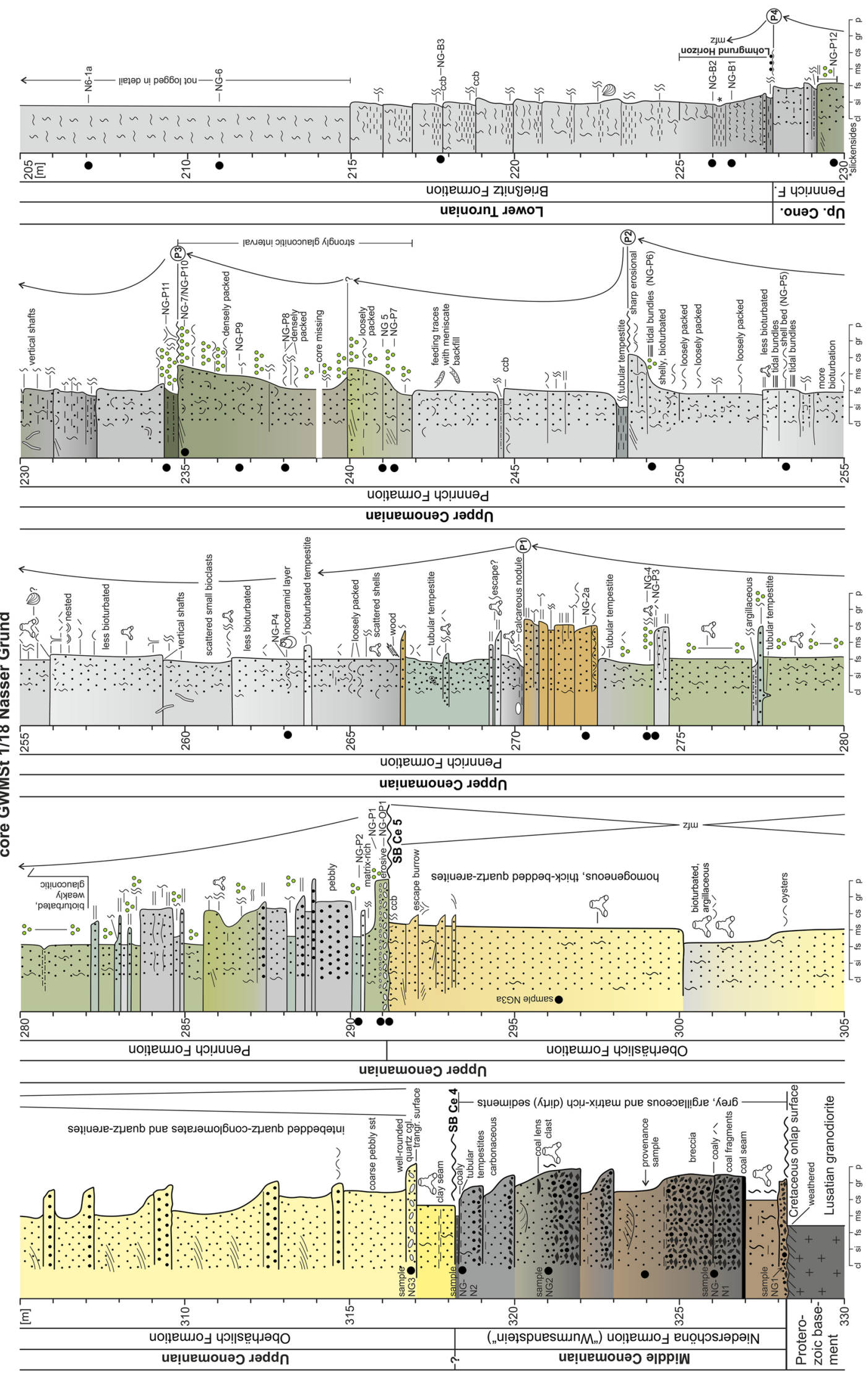


4Fig. 4 Stratigraphic log of the lower part of core GWMst 1/18 Nasser Grund near Bad Schandau (330-205 m; see Fig. 1a for locality; P1$\mathrm{P} 4$ are the terminal surfaces of sub-cycles P1 to P4 of the Pennrich Formation). Up. Ceno. Upper Cenomanian, F. Formation

Formation (Fig. 3c). Loamy to sandy Quaternary deposits containing Cretaceous pebbles and cobbles conclude the succession in the HG 6512 core section.

\section{Core Nasser Grund}

The core GWMSt 1/18 Nasser Grund has been drilled in 2018 east of Bad Schandau in the Saxonian Switzerland (Figs. 1a, 4). It reached a final depth of $330 \mathrm{~m}$ and was drilled to serve as a groundwater gauge. At $328.20 \mathrm{~m}$ depth it reached the basement consisting of the Proterozoic Lusatian granodiorite. Only the lower part of the Cretaceous succession up to a depth of $205 \mathrm{~m}$ is treated herein, specifically the Pennrich Formation between 291 and $228 \mathrm{~m}$.

The lowermost part of the Cretaceous succession between 328.20 and $318.20 \mathrm{~m}$ is formed by coarse-grained breccia, conglomerates, and coarse-grained sandstones of the Niederschöna Formation (Fig. 4). Components are mainly quartz clasts and the matrix is argillaceous-carbonaceous. Thin coal seams and lenses, as well as coaly fragments, are common. Ophiomorpha burrows have been observed at several levels. This marine-influenced upper part of the Niederschöna Formation is informally called "Wurmsandstein" and assigned to the Middle Cenomanian (Janetschke and Wilmsen 2014).

At $318.20 \mathrm{~m}$, a sharp lithofacies change to yellow-beige quartz sandstones of the Oberhäslich Formation occurs (Fig. 4). In its lower part up to $305 \mathrm{~m}$, fine-grained quartz conglomerates intercalate with coarse-grained, cross-bedded sandstones while the upper part consists of medium-grained, rather homogeneous quartz arenites with occasional bioturbation. Between 302 and $300 \mathrm{~m}$, the sandstones are fine- to medium-grained, slightly argillaceous, and show more bioturbation. A coarsening trend with reappearance of crossbedding characterized the uppermost 2-3 $\mathrm{m}$ of the formation. The Oberhäslich Formation encompasses the lower Upper Cenomanian (Tröger and Voigt in Niebuhr et al. 2007; Wilmsen 2017).

At $291.20 \mathrm{~m}$, the Oberhäslich Formation is unconformably overlain by the basal conglomerate of the upper Upper Cenomanian Pennrich Formation. The basal bed consists of varicolored, well-rounded quartz pebbles in a greenish sandy-argillaceous matrix containing matrix glaucony (Figs. 2b, 4); exotic clasts comprise dolomitized limestone and speleothem fragments. The lower Pennrich Formation consists of an intercalation of bioturbated fine- and coarsegrained sandstones, the latter often pebbly. Both lithofacies may contain grainy and/or matrix glaucony and are stacked with a fining-upward trend. From a depth of 283 $\mathrm{m}$, fine-grained, bioturbated glauconitic sandstones prevail, showing only thin sharp-based coarser interbeds (Fig. 4). At ca. $272.5 \mathrm{~m}$, the fine-grained interval is followed by coarse-grained, oyster shell-bearing brownish sandstones with cross-bedding and parallel lamination, placing the top of a coarsening-upward trend at $270.30 \mathrm{~m}$ (top of cycle P1; Figs. 2c, 4). Above the sharp top surface, cycle P2 starts with bioturbated, fine-grained sandy-argillaceous strata which are weakly glauconitic only in the lowermost part up to $267 \mathrm{~m}$. Up-section, fine- to medium-grained, bioturbated sandstones prevail, stacked into asymmetric, 4-6-m-thick thickeningupward sub-cycles (parasequences), containing scattered oyster shells or shell beds at various levels (Fig. 2d); at $267.10 \mathrm{~m}$, a single inoceramid shell bed has been observed. Tubular and stratiform tempestites occur throughout and Ophiomorpha burrows are common, including long vertical shafts (Fig. 2e). From $255 \mathrm{~m}$ up-section, a coarsening trend characterized the upper part of cycle $\mathrm{P} 2$ which is terminated by a sharp, erosional surface at $248.40 \mathrm{~m}$ (Fig. 4). In this interval, oyster shells are very common and thin bundled clay seams indicate tidal influences (Fig. 2f). Cycle P3 starts with a strongly bioturbated argillaceous horizon and ends at a sharp surface at $234.80 \mathrm{~m}$ (Fig. 4). It consists of four parasequences that are stacked with a prograding (i.e., coarsening-/thickening-) trend, the upper two of which being strongly glauconitic (Fig. 2g, h). Grainy glaucony predominates in this interval and the green grains from the uppermost part often show signs of oxidation (brown rims and/ or staining). Oyster shells are common throughout cycle P3 (Fig. 2g, h). The uppermost cycle of the Pennrich Formation (P4) starts with an argillaceous-glauconitic horizon and consists of four 1.5-2-m-thick parasequences. It is formed by predominantly fine-grained, bioturbated sandstones and contains glaucony only between 230 and $229 \mathrm{~m}$ (Fig. 4). It is (and with it the Pennrich Formation) terminated at 227.85 $m$ with an erosion surface overlain by a thin layer of intraformational pebbles, followed by an argillaceous interval up to $225 \mathrm{~m}$, forming the Lohmgrund Horizon of the basal Brießnitz Formation (Fig. 4). The Lower Turonian Brießnitz Formation consists of a m-scale cyclic succession of finegrained, strongly bioturbated, alternating more argillaceous and more calcareous silty marlstones (Pläner); only the lower part of this unit has been logged in detail (Fig. 4).

\section{Glauconitic facies types (GFTs)}

The facies analysis of the glauconitic facies within the lower Elbtal Group is based on evaluation of litho- and microfacies, supplemented by field observations of features such as bedding, sedimentary structures as well as trace and body fossil contents. On the basis of these integrated data, the glauconitic strata have been grouped into 12 facies types (GFTs), briefly described in Table 1 and 


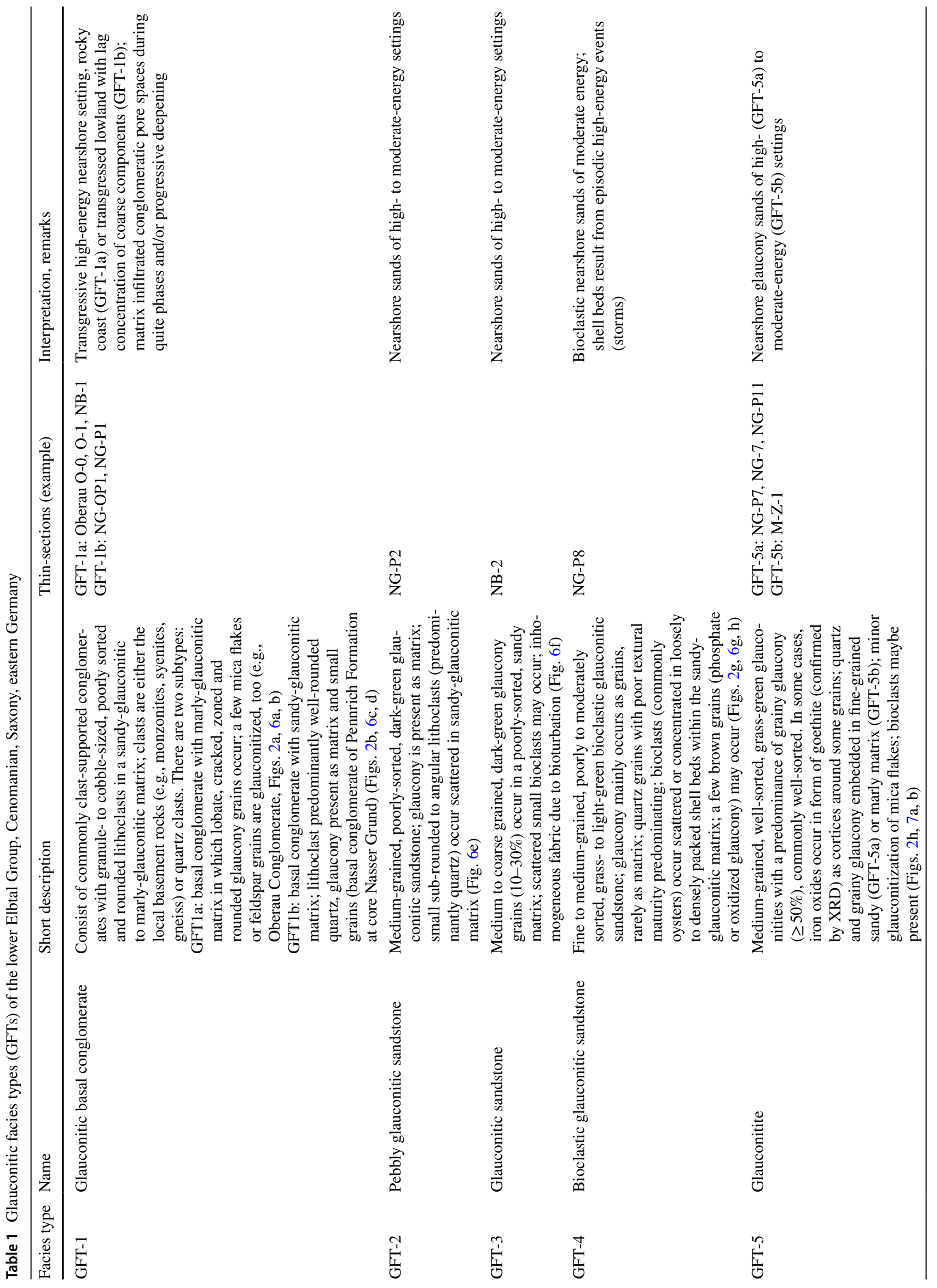




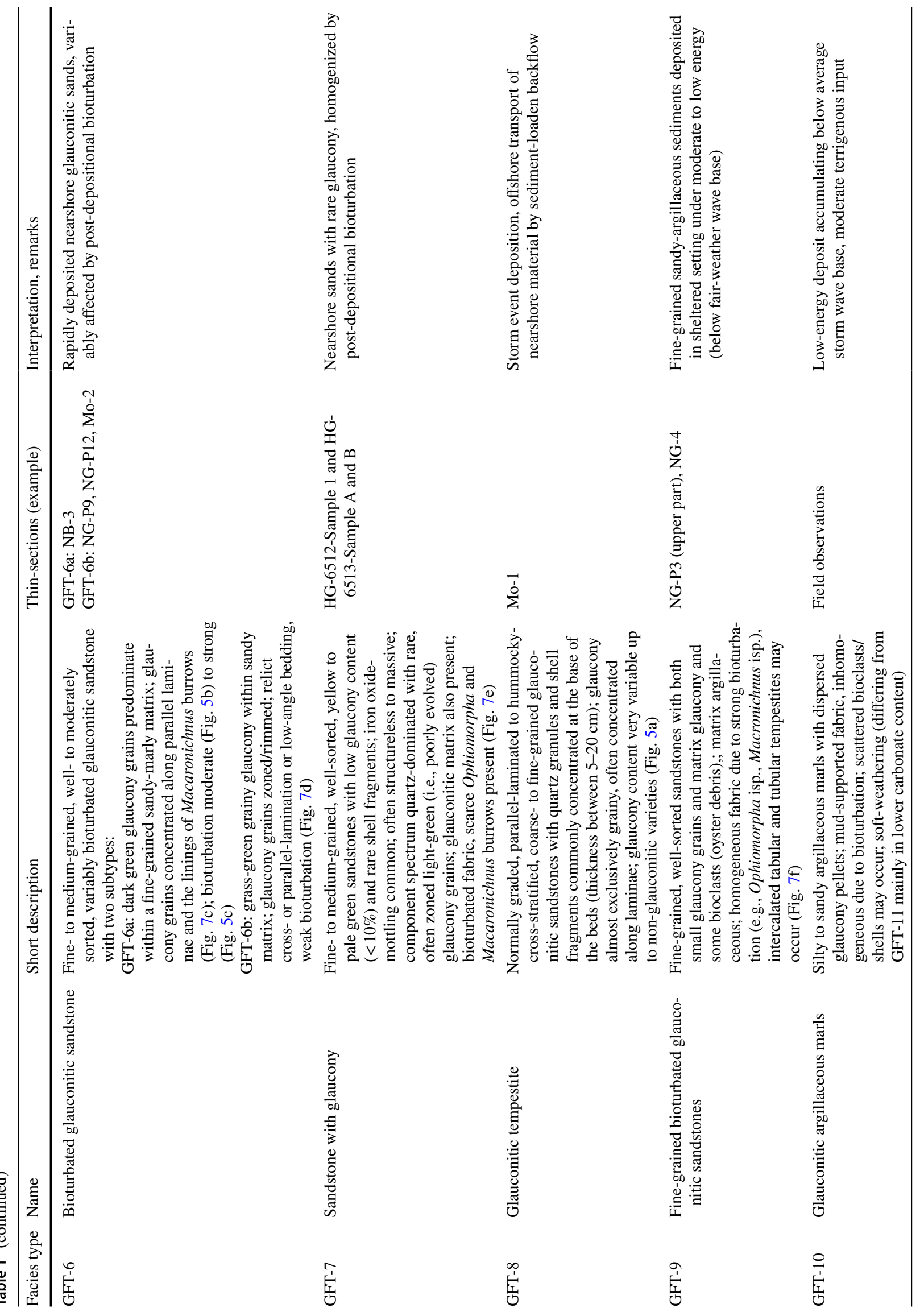




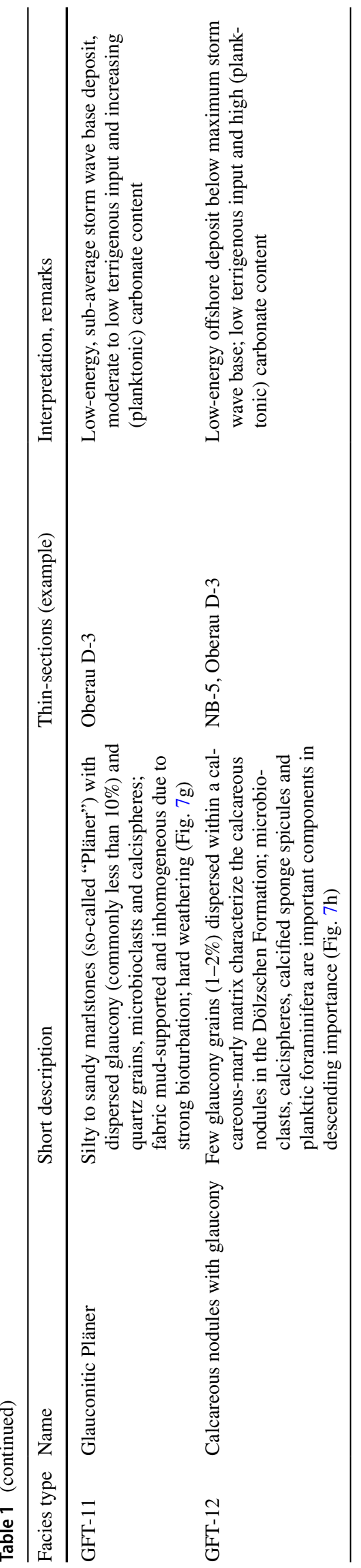

illustrated in Figs. 5, 6, 7. Thin-section photomicrographs are shown according to their original stratigraphic orientation, i.e., up-section corresponds to the page top. The GFTs have been arranged according to their grain size from coarse (GFT-1) to fine (GFT-12). Their order thus broadly corresponds to the stratigraphic occurrence in a typical transgressive fining-upward cycle in which, of course, commonly not all GFTs are developed from base to top. The following GFTs have been identified:

GFT-1: Glauconitic basal conglomerate with either marly-glauconitic (GFT-1a) or sandy glauconitic matrix (GFT-1b) (Figs. 2a, b, 6a-d).

GFT-2: Pebbly glauconitic sandstone merges mediumgrained glauconitic sandstones with scattered granule- to pebble-sized lithoclasts (commonly quartz; Fig. 6e).

GFT-3: Glauconitic sandstone, consisting of mediumto coarse-grained sandstones (Fig. 6f).

GFT-4: Bioclastic glauconitic sandstone contains scattered bioclasts and disarticulated valves, commonly of oysters (Figs. 2g, 6g, h).

GFT-5: Glauconitites consist of well-sorted, commonly medium-grained glaucony $(>50 \%)$ and quartz grains within a finer sandy (GFT-5a) and marly matrix (GFT-5b) (Figs. 2h, 7a, b).

GFT-6: Bioturbated glauconitic sandstone are fine- to medium-grained and may contain relict sedimentary structures (Figs. 5c, 7c, d).

GFT-7 (sandstone with glaucony) combines commonly structureless sandstones with a low glaucony content $(<10 \%)$ (Fig. 7e).

GFT-8: Glauconitic tempestites, comprising sharpbased, normally graded glauconitic sandstones with parallel lamination and/or hummocky cross-stratification (HCS) (Fig. 5a).

GFT-9: Fine-grained bioturbated glauconitic sandstones comprise well-sorted, strongly bioturbated sediments with matrix glaucony and small glauconitic grains (Fig. 7f).

GFT-10: Glauconitic argillaceous marls are soft sediments with scattered glaucony grains.

GFT-11: Glauconitic Pläner are bioturbated silt- and fine-sand-containing marlstones with dispersed glaucony grains (Fig. $7 \mathrm{~g}$ ).

GFT-12: Calcareous nodules with a low glaucony content (maximum 1-2\%) commonly occur in the Dölzschen Formation (Fig. 7h).

\section{XRD analyses}

X-ray diffractograms (XRD) of separated green grains in air-dried mode of scanning distinguish the clay-minerals and their association (Fig. 8). Green grains have been separated from the Mobschatz Formation of the Oberau-Gröbern area (sample O-1, lower Middle Cenomanian) and the Nossener 


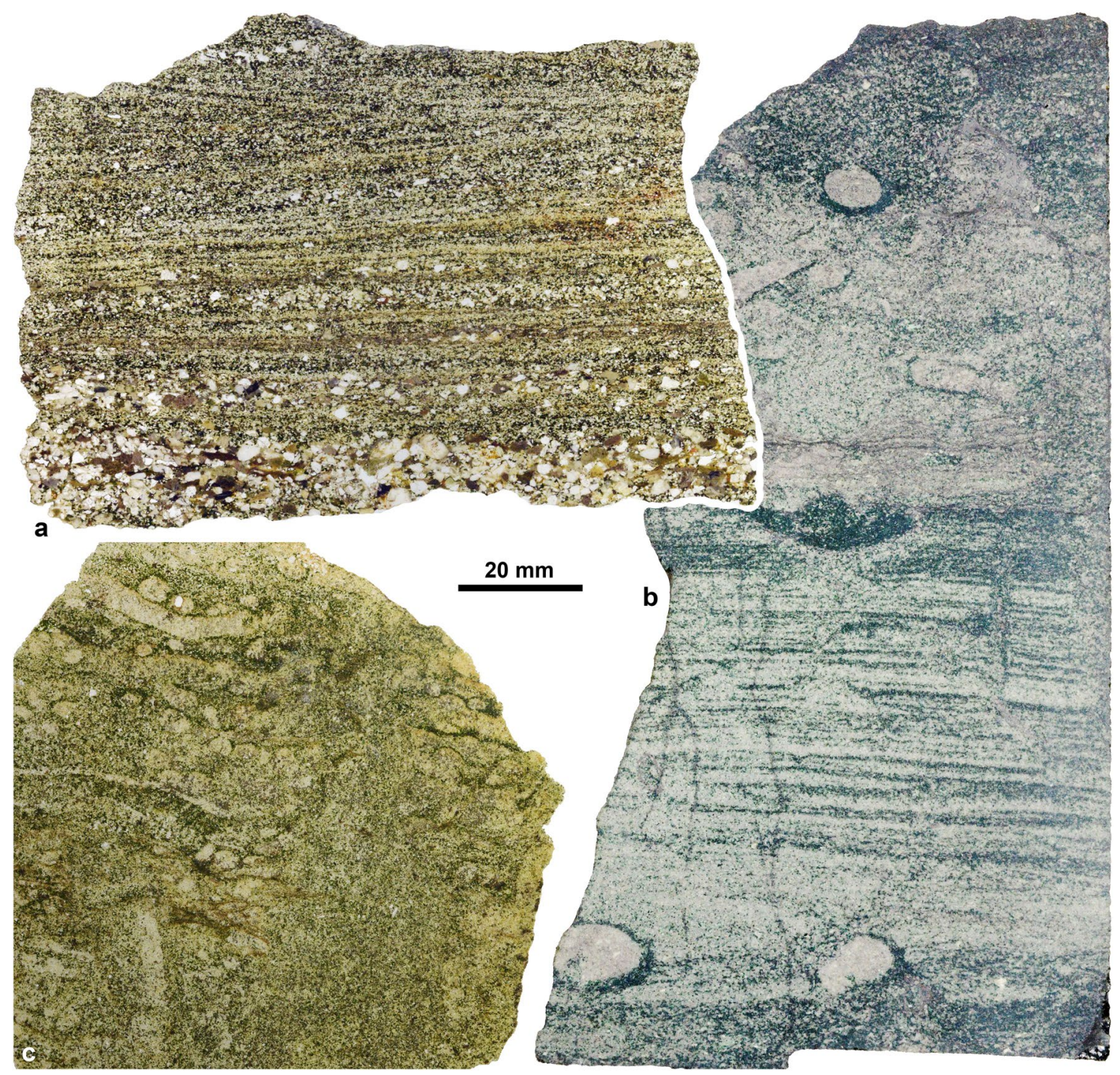

Fig. 5 Lithofacies aspects glauconitic facies types (GFTs) of the lower Elbtal Group, Saxony, Germany (polished slabs). a Graded glauconitic tempestite (GFT-8) with quartz granules and shell debris concentrated in the lower part and hummocky cross-stratification (HCS) in the upper part (sample Mo-1, temporary outcrop at motorway A4 exit DD-Altstadt). b Glauconitic sandstone with relict paral- lel lamination in lower part, penetrated by large, glaucony-lined Macaronichnus burrows (GFT-6a), grading into a strongly bioturbated marly greensand above (GFT-6b) (sample NB-3, lower part of section Nossener Brücke). c Strongly bioturbated marly greensand of GFT-6b (sample Mo-2, temporary outcrop at A4 motorway exit DD-Altstadt)
Brücke core (samples NB-1 and -3, lower Upper Cenomanian) as well as the from the Pennrich Formation at core Nasser Grund (sample NG-7, upper Upper Cenomanian). Sample O-1 reveals the basal reflection at $10.09 \AA(001)$ as well as reflections at $4.53 \AA(020), 3.65 \AA(11 \overline{2}), 3.33 \AA$ (003), $3.06 \AA$ (112), $2.58 \AA$ (004), $1.99 \AA$ (005) and $1.51 \AA$ (060) (Thompson and Hower 1975; Odin and Matter 1981; Amorosi et al. 2007) with sub-ordinate peaks at $2.80 \AA$, $2.70 \AA$ and $1.84 \AA$ (Fig. 8a). The peaks are intense, sharp, symmetrical and narrow-based. Similarly, the XRD diagrams of samples NB-1 and NB-3 exhibit the basal (001) reflection at $10.16 \AA$, a (003) reflection at $3.33 \AA$, a (004) reflection at $2.57 \AA$ and a (005) reflection at $1.99 \AA$. Other prominent peaks include the reflections $(020)$ at $4.53 \AA$ and (060) at $1.51 \AA$ (Odin and Matter 1981; Amorosi et al. 2007; Fig. 8b). Sample NB-3 further exhibits the shoulder reflections $11 \overline{2}$ and 112 at $3.64 \AA$ and $3.08 \AA$, respectively (Fig. 8c). The peaks are narrow-based, sharp, symmetrical and intense. Subsidiary peaks occur at $7.14 \AA$ and at $4.99 \AA$ in sample NB-1, indicating kaolinite and illite, respectively (Fig. 8b), the latter peak also occurring at $4.98 \AA$ in sample NB-3 (Fig. 8c). Finally, also sample NG-7 (Pennrich Formation) reveals the peaks at $10.15 \AA(001)$, followed by (020) at $4.53 \AA,(11 \overline{2})$ at $3.66 \AA,(003)$ at $3.33 \AA$, (004) at 

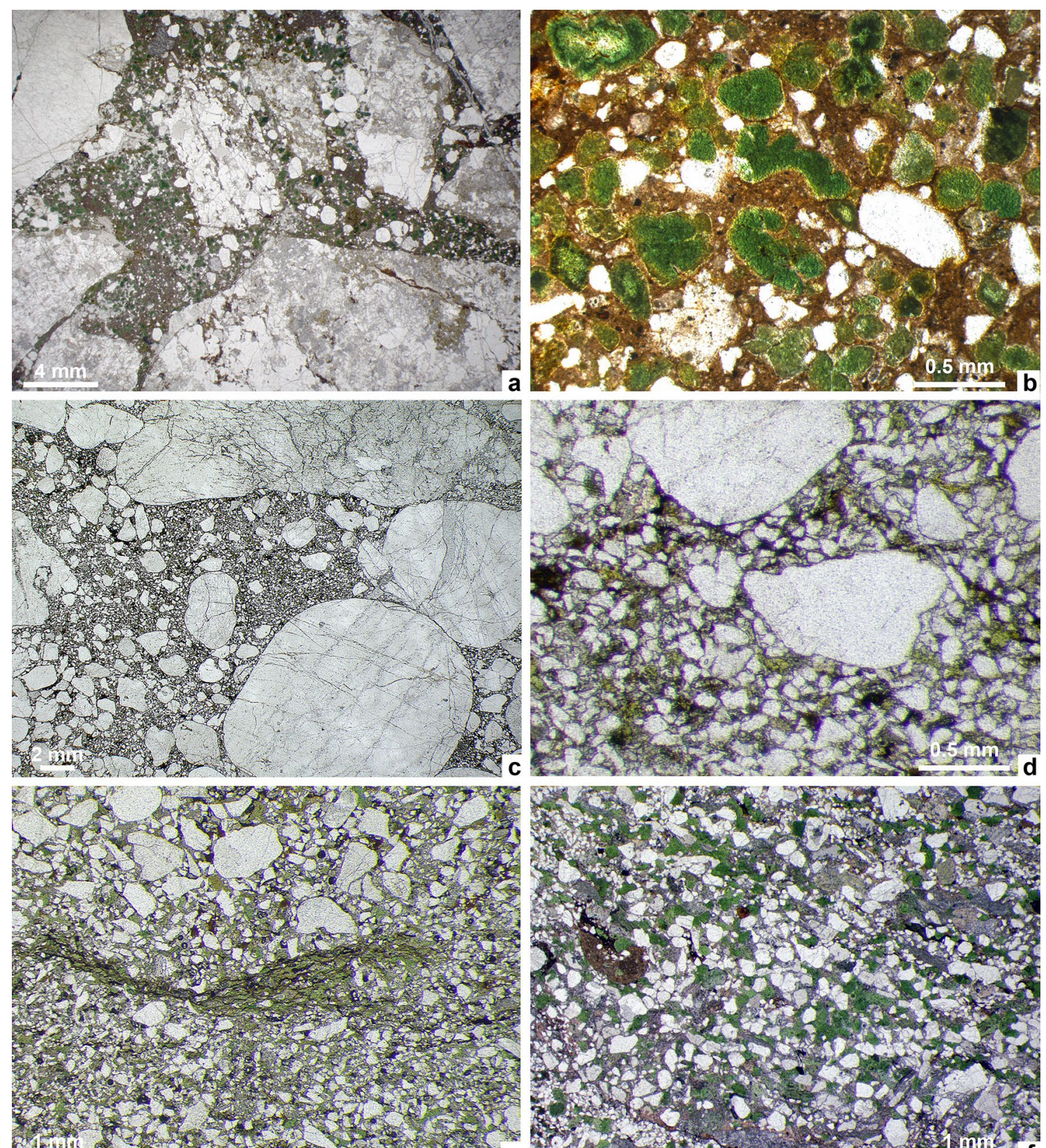

Meres gin

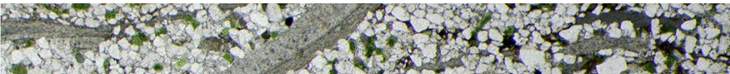

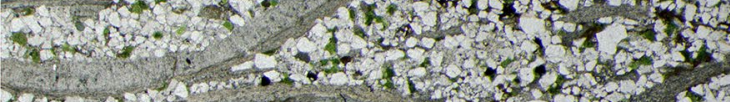

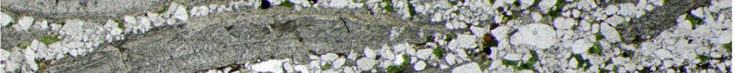

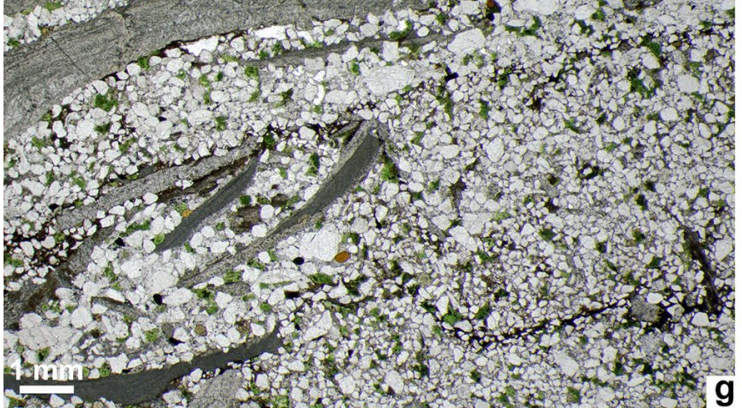

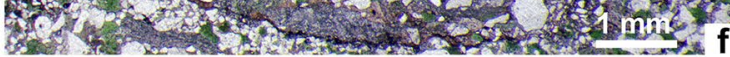

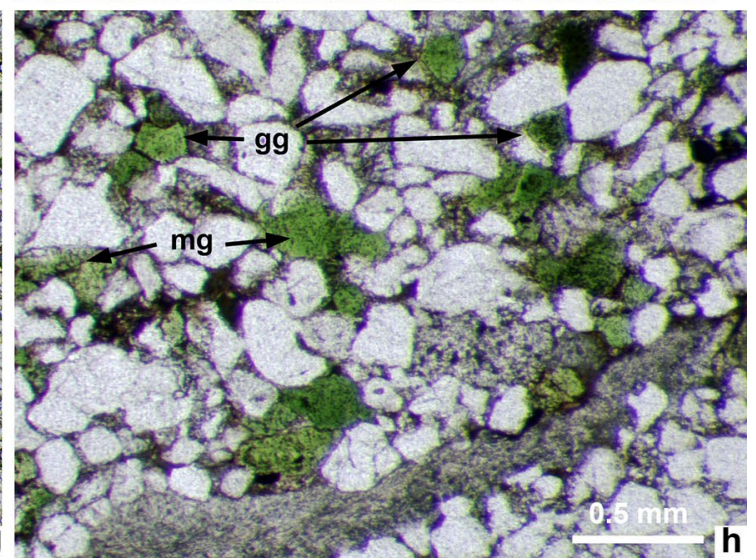


4Fig. 6 Microfacies aspects of glauconitic facies types (GFT) of the lower Elbtal Group, Saxony, Germany. a Basal conglomerate of GFT1a, lower Middle Cenomanian Oberau Conglomerate, Oberau area, sample O-1; note (sub-)angular, partly disintegrating gneiss clasts (light grey) and the dark grey, glauconitic matrix. b Close-up of the glauconitic matrix of the basal conglomerate of GFT-1a, lower Middle Cenomanian Oberau Conglomerate, Oberau area, sample O-0; note lobate, cracked, zoned and round glaucony grains. $\mathbf{c}$ basal conglomerate of GFT-1b, mid-Upper Cenomanian conglomerate at the base of the Pennrich Formation, core Nasser Grund at $291.10 \mathrm{~m}$, sample NG-OP1; note well-rounded quartz pebbles. d Close-up of the sandy-glauconitic matrix of the basal conglomerate of GFT-1b, mid-Upper Cenomanian conglomerate at the base of the Pennrich Formation, core Nasser Grund at 291.10 m, sample NG-OP1. e Pebbly glauconitic sandstones of GFT-2, mid-Upper Cenomanian, lower part of the Pennrich Formation, core Nasser Grund at 290.30 m, sample NG-P2. f Poorly sorted glauconitic sandstone of GFT-3, Mobschatz Formation, lower Upper Cenomanian, core Nossener Brücke at $75.6 \mathrm{~m}$, sample NB-2. g Bioclastic glauconitic sandstones of GFT-4 showing numerous thick-shelled oyster shell fragments, upper Upper Cenomanian Pennrich Formation, core Nasser Grund at 238 m, sample NG-P8. h Close-up of GFT-4, bioclastic glauconitic sandstones, showing both, grass-green glaucony grains (gg) and matrix glaucony $(\mathrm{mg})$; upper Upper Cenomanian Pennrich Formation, core Nasser Grund at $238 \mathrm{~m}$, sample NG-P8

$2.58 \AA,(005)$ at $1.99 \AA$ and (060) at $1.51 \AA$ (Odom 1984; Banerjee et al. 2016; Fig. 8d). Sub-ordinate peaks at 4.18 $\AA$, $2.68 \AA$, and $2.45 \AA$ indicate the presence of goethite. All the peaks are sharp, intense, and symmetrical with narrow bases (Fig. 8d). The characteristic peak at $10 \AA$ in all studied samples belongs to the 'glauconitic' minerals group (cf. Odin and Fullagar 1988) while the sub-ordinate peaks at $2.80 \AA, 2.70 \AA$, and $1.84 \AA$ in sample O-1 indicate the presence of fluorapatite/carbonate-fluorapatite within these glauconitic grains.

\section{Discussion}

\section{Clay mineralogy}

The XRD analyses of green grains extracted from Cenomanian samples of the lower Elbtal Group in Saxony revealed that the constituting mineral is in any case a $10-\AA$-mineral of the glaucony group (Fig. 8). The X-ray scanning of green grains from the lower Middle (sample O-1) and lower Upper Cenomanian of the Mobschatz Formation (samples NB-1 and NB-3) clearly identifies the green mineral as a glauconitic mineral with minor illite (Thompson and Hower 1975; Odin and Matter 1981; Odom 1984; Amorosi et al. 2007; Banerjee et al. 2016). The X-ray diffractogram of sample $\mathrm{O}-1$ indicates an association of the glauconitic mineral with fluroapatite/carbonate-fluroapatite. Petrographical studies relate the presence of the latter to the occurrence of small phosphatized vertebrate fragments (fish remains). The occurrence of kaolinite in sample NB-1 can be attributed to the chemical alteration of K-feldspars provided by the underlying basement rocks. The X-ray diffractogram of sample NG-7 (upper Upper Cenomanian Pennrich Formation) reveals the co-occurrence of the glauconitic mineral and goethite. Detailed thin-section petrography from that level corroborates the presence of goethite as iron oxide within the strata. The presence of goethite is possibly related to intra-formational sub-aerial exposure of the glauconitic sediments at cycle boundary P3 and the resultant oxidizing conditions, transforming glauconitic grains (partially) into iron hydroxides (see chapter on Spatio-temporal distribution of glauconitic strata below).

\section{Glauconitic facies types}

Glauconitic facies types in the Cretaceous of Saxony have been defined and systematically analyzed as early as in 1850 by Hanns Bruno Geinitz. He differentiated glauconitic sandstones ("Grünsandstein"), glauconitic sands ("Grünsand"), glauconitic calcareous sandstones, glauconitic Pläner and calcareous glauconitic nodules, the latter commonly occurring in the plenus Pläner of the Dölzschen Formation. In its main features, his early lithofacies subdivision already back then reflected a proximal-distal gradient and broadly corresponds to the glauconitic facies types identified herein.

The glauconitic facies types (GFT) 1-12 (Table 1) recognized in this study contain granular and matrix glaucony. When the mineral occurs as a coating (film facies) or as pore-filling matrix, glaucony can always be supposed to be autochthonous (e.g. Odin and Matter 1981; Amorosi 1995, 1997) and is, with a few exceptions, a reliable indicator of marine conditions (Banerjee et al. 2016). Grainy glaucony, on the other hand, can be both, authothonous and allochthonous, and grainy glauconitic facies must therefore be evaluated with care. However, the grainy glauconitic facies observed in the Mobschatz, Oberhäslich and Pennrich formations of Saxony by no means represents detrital (extrasequential) glaucony (Amorosi 1995, 1997), transported from an external source area into the basin, because no appropriate source rocks are present in the wider area and the transport capacity of glaucony is low. Thus, the glauconitic facies types in Saxony exclusively consist of authochthonous and parauthochthonous (intrasequential) glaucony sensu Amorosi (1997). For the grainy facies types, a parauthothonous nature of the grains in the case of GFT-8 (graded glauconitic tempestites with HCS) can easily be derived from their arrangement in cross-laminae. The occurrence of shrinkage fractures at grain surface, on the other hand, such as in many green grains from the matrix of the glauconitic conglomerates (GFT-1), is a reliable indicator of an authothonous origin of glauconite (McRae 1972; Odom, 1976; Fischer 1990). However, in detail, the differentiation of grainy glaucony 

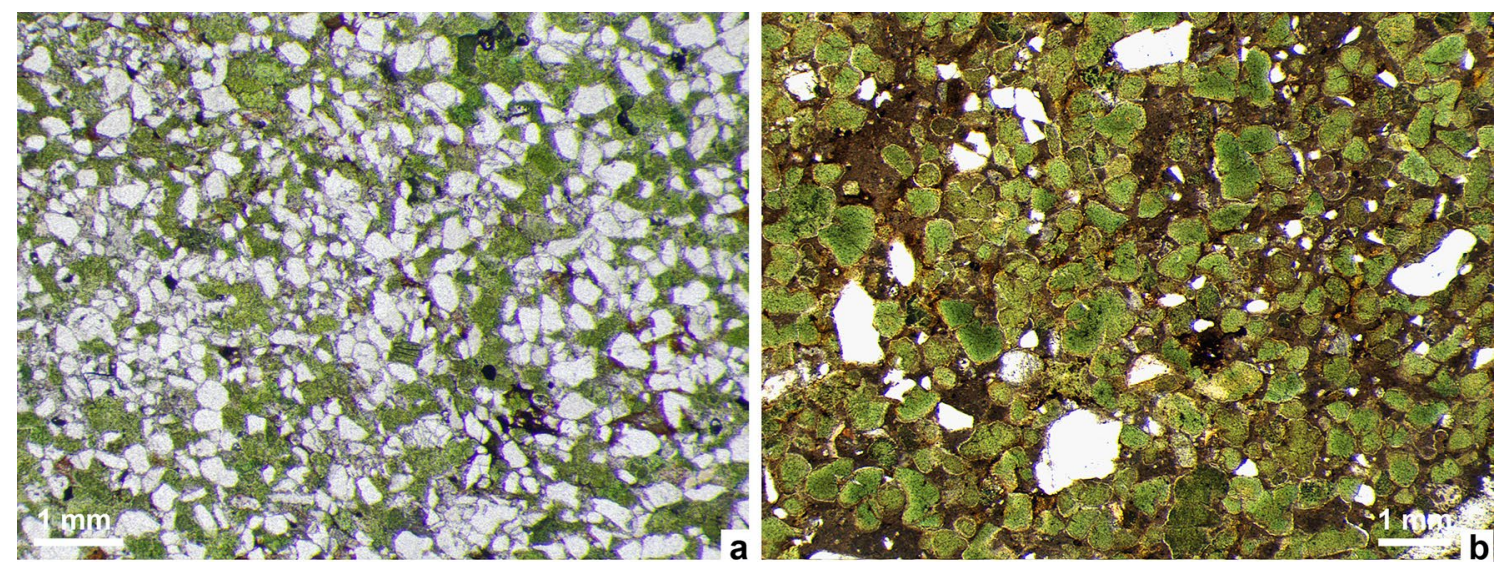

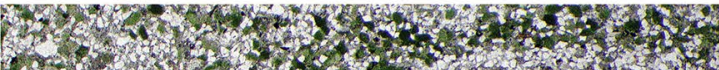

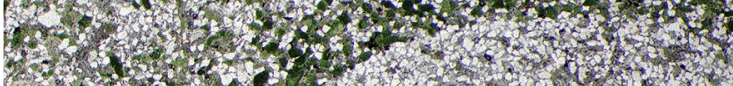
W6. m.

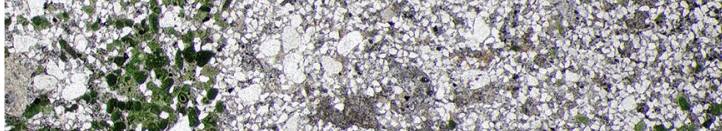

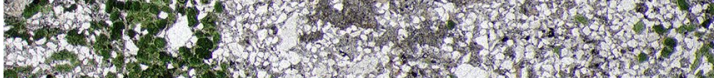

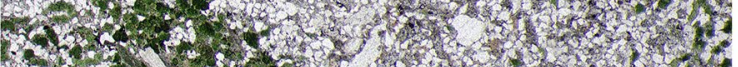

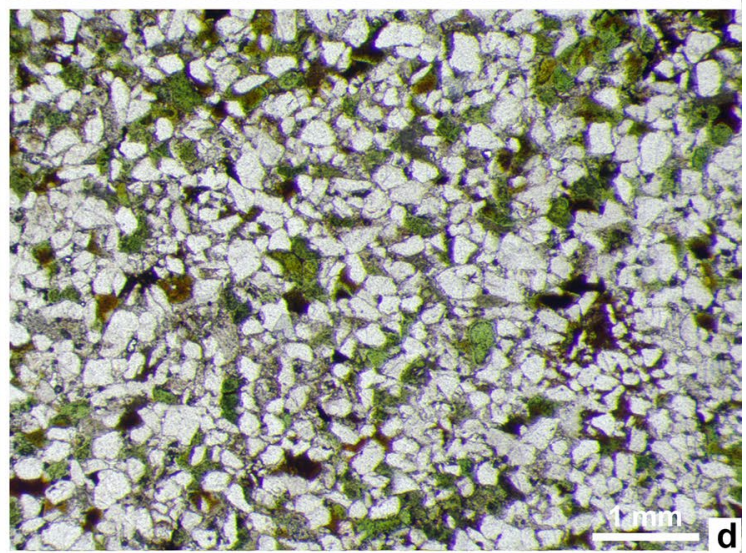

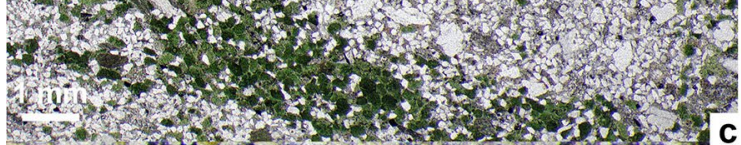

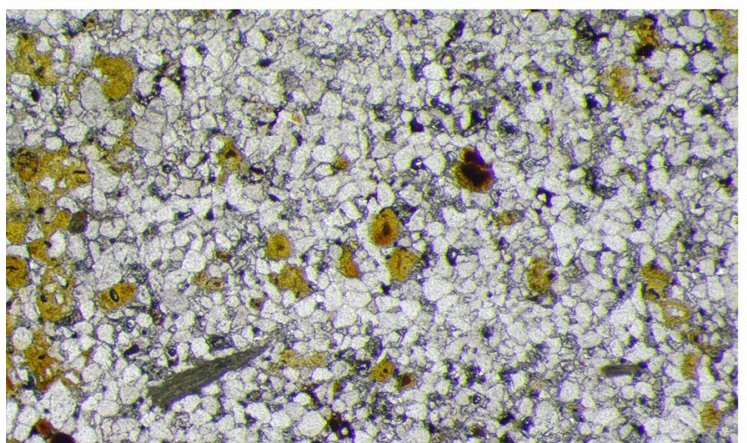

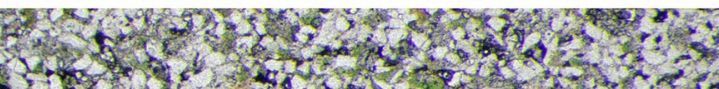

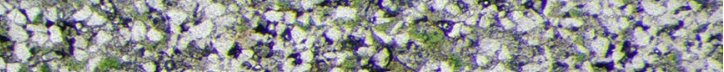

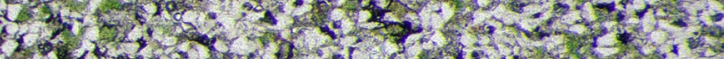

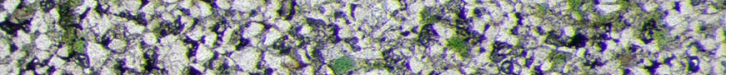

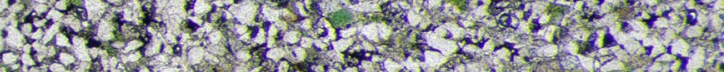

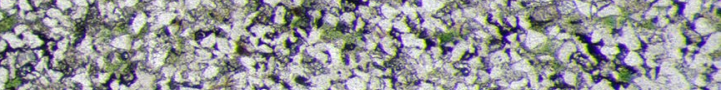

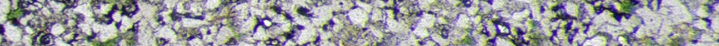

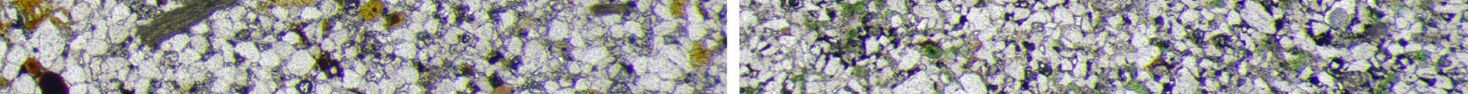

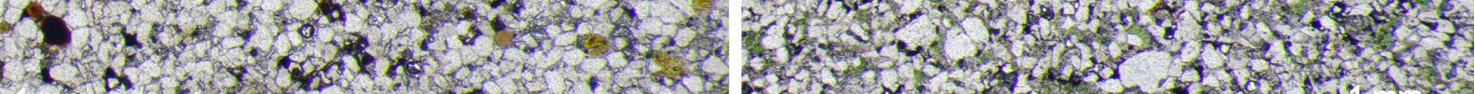

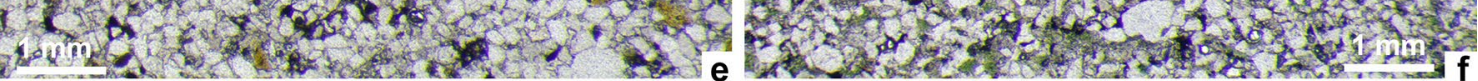

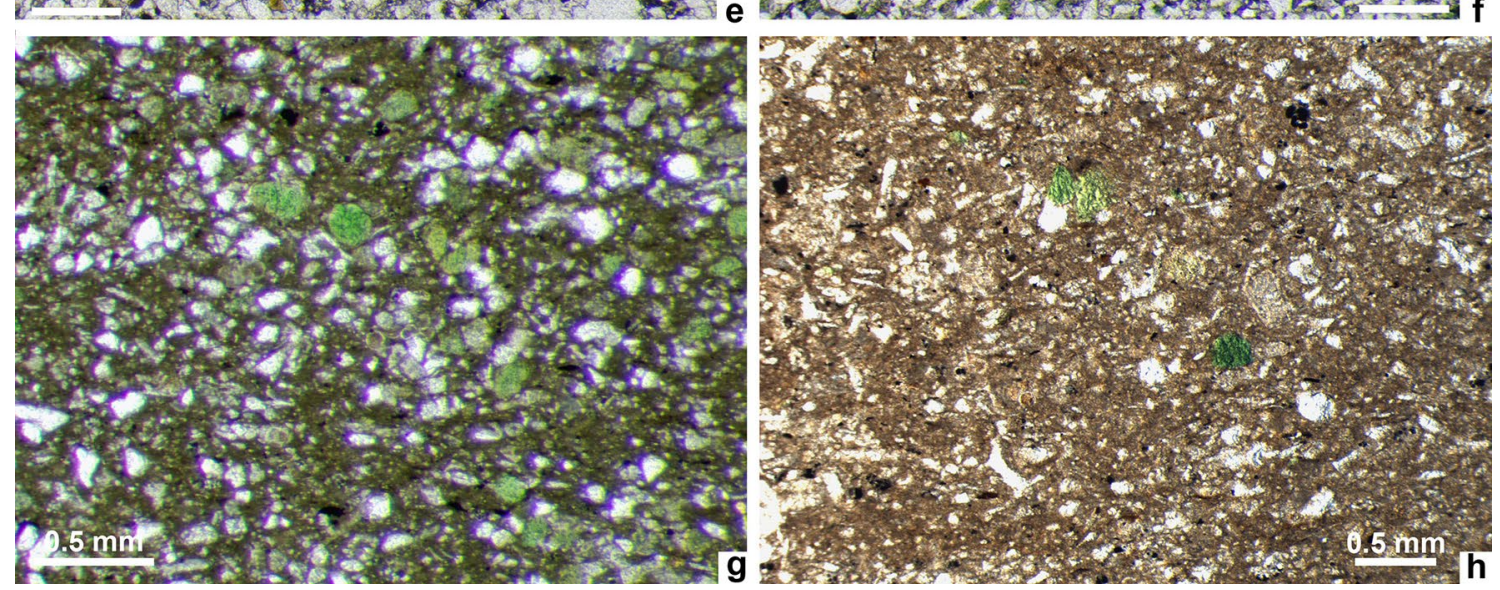


4Fig. 7 Microfacies aspects of glauconitic facies types (GFT) of the lower Elbtal Group, Saxony, Germany. a Sandy glauconitite of GFT-5a, upper Upper Cenomanian Pennrich Formation, core Nasser Grund at 235 m, sample NG-7. b Marly glauconitite of GFT-5b, lower Upper Cenomanian Mobschatz Formation in Meißen-Zscheila, sample M-Z-1; note variable shape of the glaucony grains. c Bioturbated glauconitic sandstone of GFT-6a, lower Upper Cenomanian Mobschatz Formation, core Nossener Brücke, sample NB-3, showing segregation of glaucony grains at the margin of a large Macaronichnus burrow. d Bioturbated glauconitic sandstone GFT-6b, upper Upper Cenomanian Pennrich Formation, core Nasser Grund at 236.7 $\mathrm{m}$, sample NG-P9. e Medium-grained sandstone with light-colored glaucony (GFT-7), lower Upper Cenomanian Oberhäslich Formation, core HG 6513 Mariaschacht at $2.1 \mathrm{~m}$, sample B. f Fine-grained, bioturbated glauconitic sandstones of GFT-9, upper Upper Cenomanian Pennrich Formation, core Nasser Grund at $274.2 \mathrm{~m}$, sample NG-P3. g Glauconitic silty-sandy marlstone (Pläner) of GFT-11, Middle Cenomanian part of the Mobschatz Formation, Gröbern composite section at $11.7 \mathrm{~m}$, sample D3. h Calcareous nodules with glaucony (GFT-12), upper Upper Cenomanian Dölzschen Formation, Gröbern composite section at $27.8 \mathrm{~m}$, sample D4

into clear-cut authothonous and parauthothonous facies may be challenging and is not always unambiguous.

When observed in a stratigraphic succession, GFT-1 to GFT-12 commonly occur superimposed in transgressive cycles starting with the glauconitic basal conglomerates (GFT-1). Up-section, medium- to coarse-grained, in part pebbly glauconitic sandstones and/or sandy glauconitites grading into (increasingly marly) bioturbated glauconitic sandstone (GFT-2-7) follow (e.g., lower part of the sections in Gröbern and Nossener Brücke; Fig. 3a, b). Graded glauconitic tempestites with hummocky cross-bedding are intercalated into the lower part of the transgressive cycles, too (GFT-8). Fine-grained, argillaceous, bioturbated glauconitic sandstones with matrix glaucony (GFT-9), argillaceous glauconitic marls and marlstones (GFT-10 and -11) continue the retrogradational fining-upward trend. Glauconitic calcareous nodules (GFT-12) are the distalmost glauconitic facies type observed in the lower Elbtal Group, characterizing the finegrained offshore facies (calcisphere- and radiolaria-bearing wackestones with planktic foraminifers) of the Dölzschen Formation. When applying Walther's law of facies, the vertical facies succession with the upwards decreasing glaucony content clearly indicates that the center of production and deposition of glaucony in the Cenomanian of Saxony was the nearshore zone (as already pointed out by Seifert 1955), nourishing disbelief in the doctrine of a deep-water origin of glaucony (cf. Odin and Matter 1981; Odin and Fullagar 1988; Föllmi 2016; Tang et al. 2017; see chapter on Prerequisites for glaucony formation below).

\section{Spatio-temporal distribution of glauconitic strata}

Green authigenic clays within sedimentary strata include a broad spectrum of minerals, i.e., iron smectite, glauconitic smectite, smectitic glauconite, berthierine, odinite (formerly phyllite v), a ferric chlorite (phyllite c), chamosite, ferric illite, or celadonite (Huggett 2005). When observed within

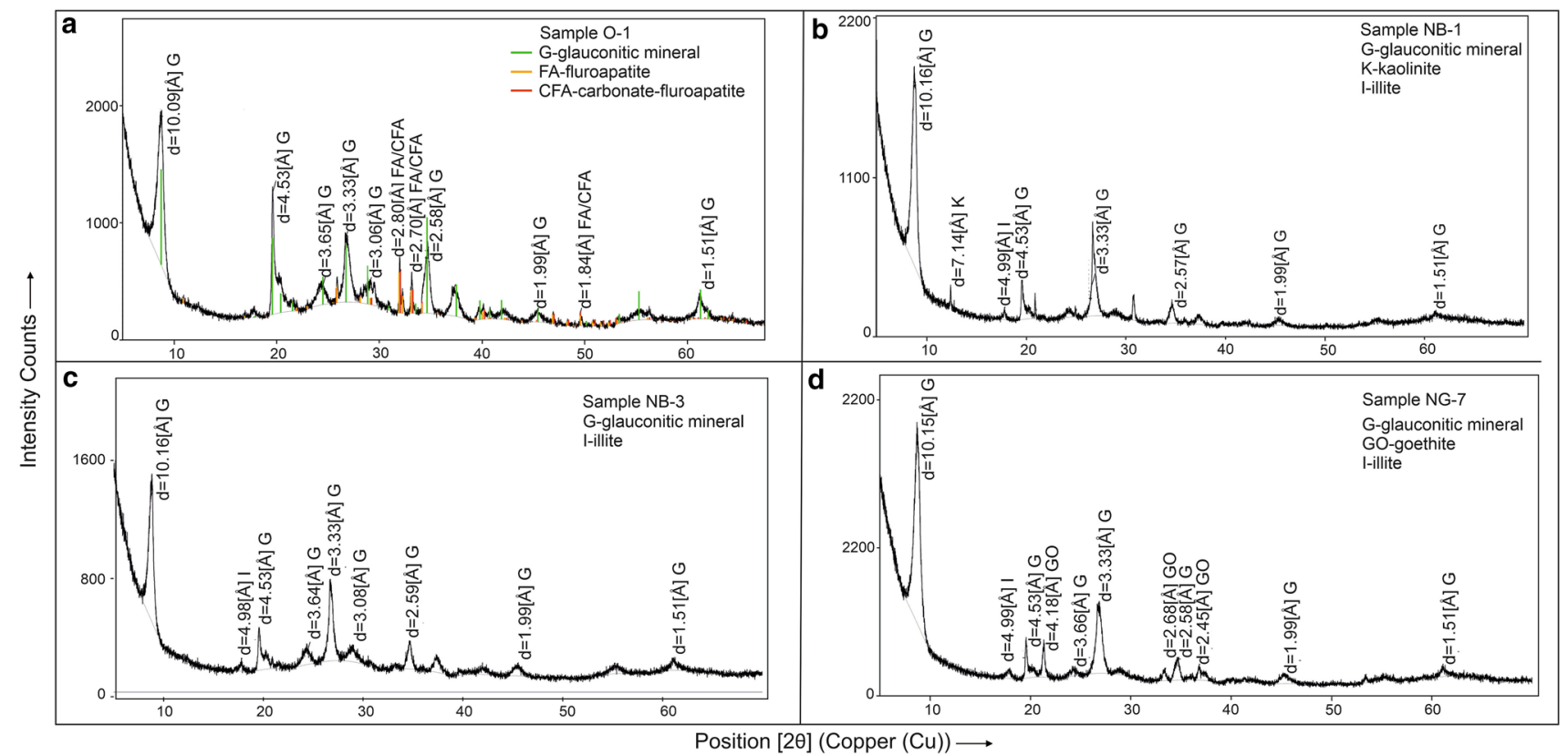

Fig. 8 XRD diagrams of green grains picked from selected samples of the lower Elbtal Group. a Sample O-1 (lower Mobschatz Formation, lower Middle Cenomanian, Oberau). b Sample NB-1 (Mobschatz Formation, lower Upper Cenomanian, core section
Nossener Brücke). c Sample NB-3 (Mobschatz Formation, lower Upper Cenomanian, core section Nossener Brücke). d Sample NG-7 (Pennrich Formation, uppermost Cenomanian, core section Nasser Grund) 


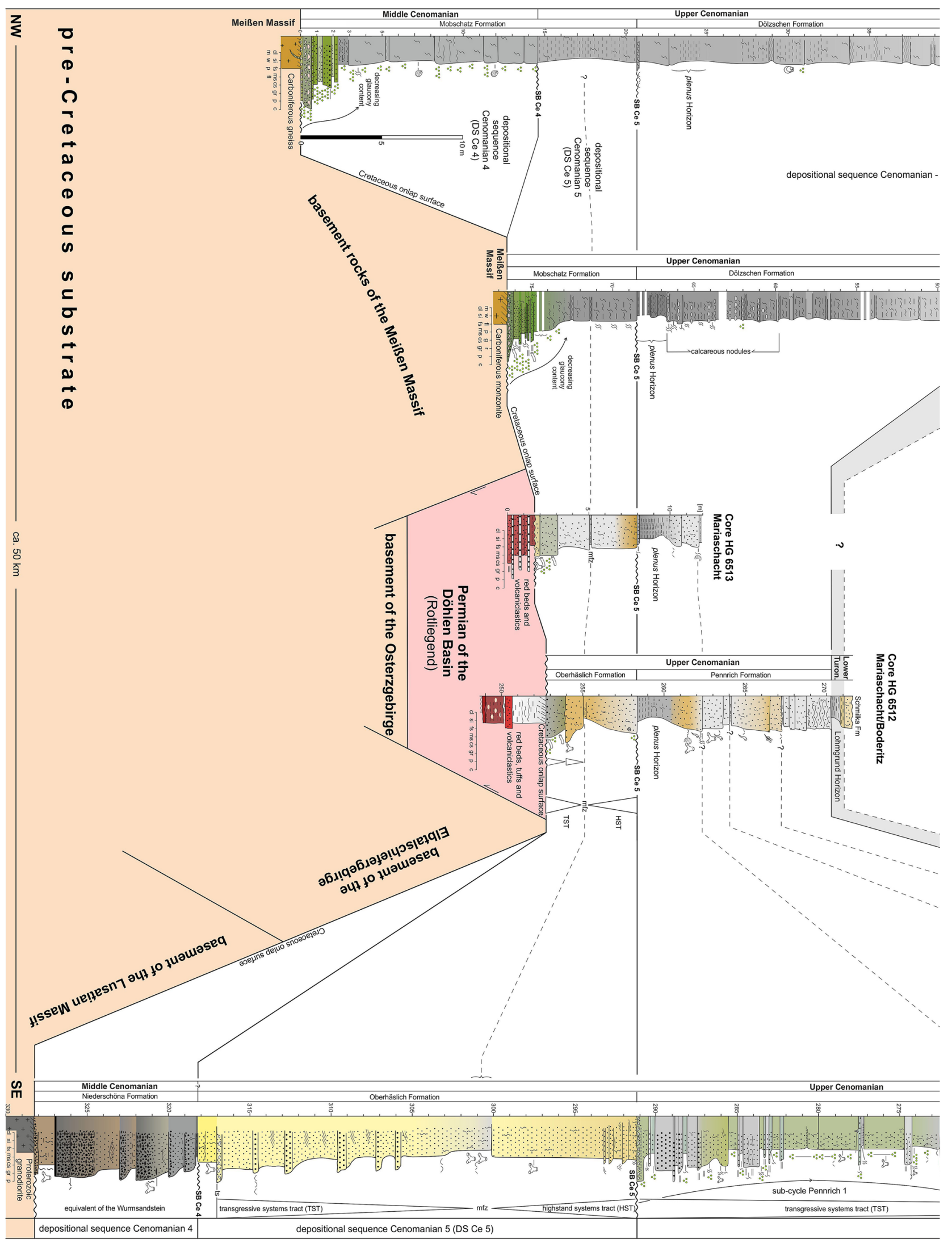



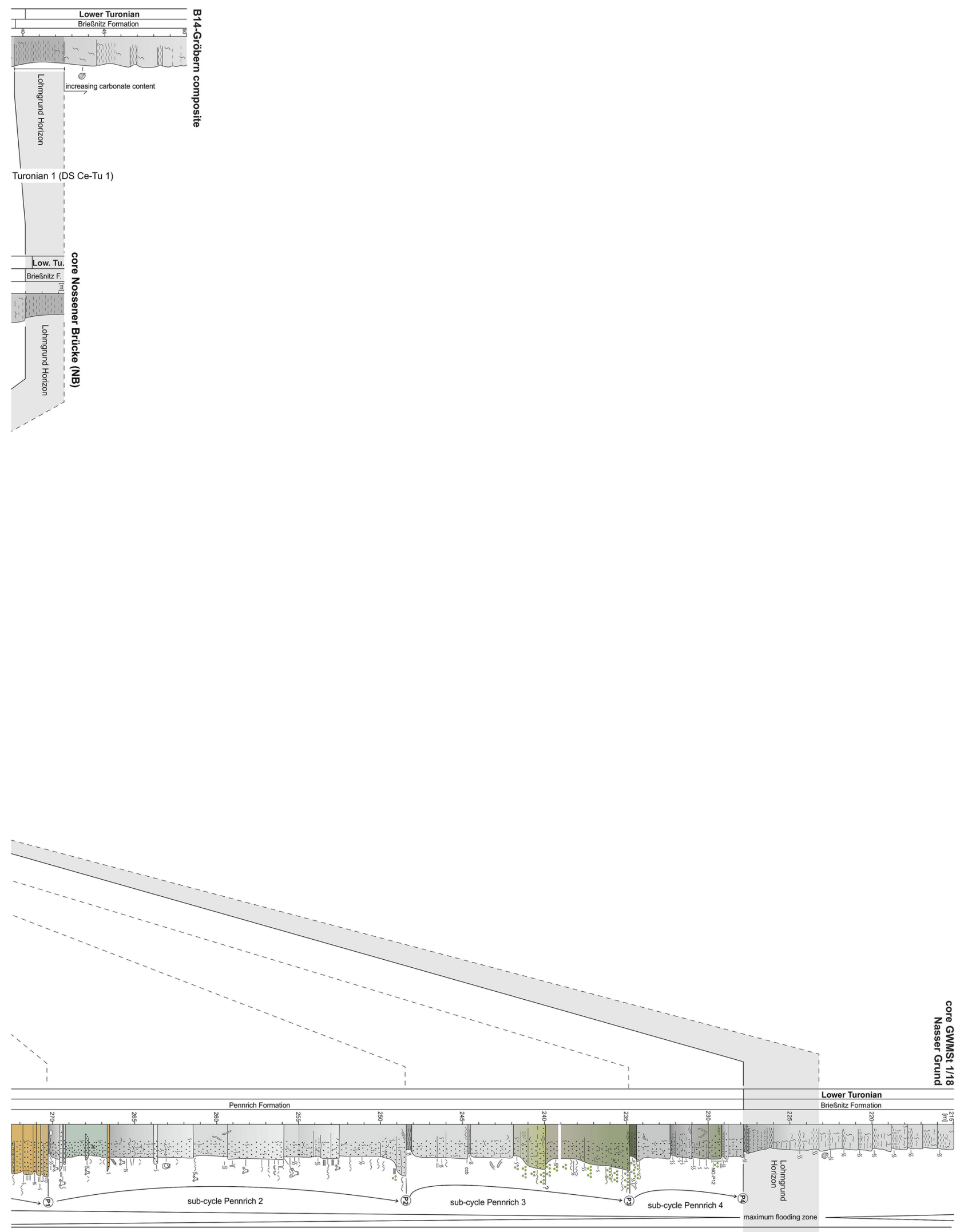

depositional sequence Cenomanian-Turonian 1 (DS Ce-Tu 1 )

Fig. 9 (continued) 
4 Fig. 9 Correlation diagram of the studied sections illustrating the stratigraphic distribution of Cenomanian strata in Saxony; the datum line is the mid-Late Cenomanian sequence boundary SB Ce 5, corresponding to the formational boundary between the Mobschatz and Dölzschen formations (northwestern part of the study area) and the boundary between the Oberhäslich and Pennrich formations (southeastern part of the study area); see text for further explanations

the sediment, green grains are commonly termed "glauconite"-mostly without analysing the exact chemical composition or mineralogy. Influential studies of "green marine clays" led to popular classification and formation theories mainly based on observations in recent environments (e.g., Odin and Matter 1981; Odin 1988). Allegedly, glauconitisation, i.e., the formation of $10-\AA$ glauconitic smectite and smectitic glauconite characterizing the glaucony facies, only occurs in fairly deep marine settings under cooler temperatures, low accumulation rates, and on long timescales (outer shelf to upper slope; Odin and Fullagar 1988) while shallow marine warm-water settings are characterized by the verdine facies with a different suite of rather rapidly forming green 7- $\AA$ clay minerals such as odinite and ferric chlorite (Odin and Sen Gupta 1988; Odin 1990). However, the geological record of the verdine facies is scarce with only a few occurrences in pre-Quaternary strata (e.g., Harding et al. 2014) and several new findings show a mismatch between the recent mode of glaucony formation and ancient examples (e.g., Chafetz and Reid 2000; El Albani et al. 2005; Chafetz 2007; Banerjee et al. 2012, 2016; Huggett et al. 2017; Bansal et al. 2018, 2020).

This mismatch, which may be referred to as the "dilemma of nearshore glaucony", is also corroborated by the occurrence of glaucony in the lower Elbtal Group. In most cases, the glaucony-rich strata occur at the bases of transgressive fining-upward cycles, already noted in earlier works (e.g., Seifert 1955; Tröger 1956), corresponding to the (lower) transgressive system tracts (TSTs) of depositional sequences, and they are almost always associated with shallow-water facies (Figs. 3, 9; see Janetschke and Wilmsen 2014; Janetschke et al. 2015; Wilmsen et al. 2019 for details on Cenomanian-Lower Turonian sequence stratigraphy of the Elbtal Group). The lower Middle Cenomanian Oberau Conglomerate of the lower Mobschatz Formation in the northwestern part of the study area is a high-energy deposit forming close to a retreating rocky coast (GFT-1). Even if the marly-glauconitic matrix infiltrated the pore space between the coarse basement components during lowered energy, e.g., during prolonged fair-weather conditions or during proceeding sea-level rise of depositional sequence DS Ce 4 (Fig. 9), a shallow-water nearshore formation of the glaucony grains is assured; their onshore transport is more than unlikely given the rarity/absence of glaucony in the offshore facies zone (see GFTs above) and appropriate onshore transport mechanisms (rather, an offshore transport of glaucony is indicated by the glauconitic tempestites of GFT-8). The same considerations apply for the lower Upper Cenomanian glauconitic conglomerate at the base of the Mobschatz Formation (depositional sequence DS Ce 5) in the Dresden area which is, in terms of lithofacies and general sequence stratigraphic position, almost identical to the older Oberau Conglomerate (Fig. 9). Furthermore, the up-section decrease in glaucony content above the basal conglomerates accompanied by decreasing grain size and increasing carbonate content suggest an increasing distance of the glauconitic zone (and depocenter) during deepening of the depositional environment (TST). When simply applying Walther's law of facies to the transgressive successions of the Mobschatz Formation, a conglomeratic-glauconitic to sandy-glauconitic nearshore facies zone is distally followed by poorly to nonglauconitic marly-calcareous offshore facies (see also Berensmeier et al. 2018a, b for a similar setting in the Münsterland Cretaceous Basin). The intercalation of sharp-based, parallel-laminated or hummocky cross-stratified glauconitic sandstones in the lower part of the transgressive cycles, representing classic tempestites that absorbed their sediments during a storm event in the coastal zone and transported it basinward with a bottom current (e.g., Seilacher and Aigner 1991; Myrow and Southard 1996), gives further evidence for the nearshore origin of the green grains. Their up-section decrease during the transgressive systems tracts also demonstrates that maxima of authochthonous glaucony in depositional sequences cannot uncritically be used to identify maximum flooding surfaces (Amorosi 1995; Udgata 2007; Amorosi et al. 2012) because other factors than solely condensation, such as the geochemical environment and suitable substrates, similarly impact the glauconitization process.

In contrast to the (upper) Mobschatz Formation, the transgressive strata at the base of the lower upper Cenomanian Oberhäslich Formation (depositional sequence DS Ce 5) are only faintly glauconitic (GFT-7), yielding light-green, poorly evolved glaucony grains, and the middle and upper parts are largely glaucony-free (Figs. 3c, d, 9; Geinitz 1850 already noted that at Rippien and Welschufe, close to the drilling sites of cores HG 6512 and 6513, the basal strata of the Oberhäslich Formation are weakly glauconitic). Obviously, the relatively clean quartz arenites of this formation reflect an environment unsuitable for widespread glaucony formation, either due to constant reworking and/or the absence of organic matter and argillaceous material. According to Harder (1980), the presence of labile organic matter and its microbial degradation is critical in creating favorable redox conditions at the interface between oxidizing and slightly reducing zones suitable for glaucony formation (Meunier and El Albani 2007). In such micro-milieus, rapid degradation of organic matter and accompanying, in part microbially catalyzed dissolution of K-feldspar, Fe-(oxy)hydroxides, 


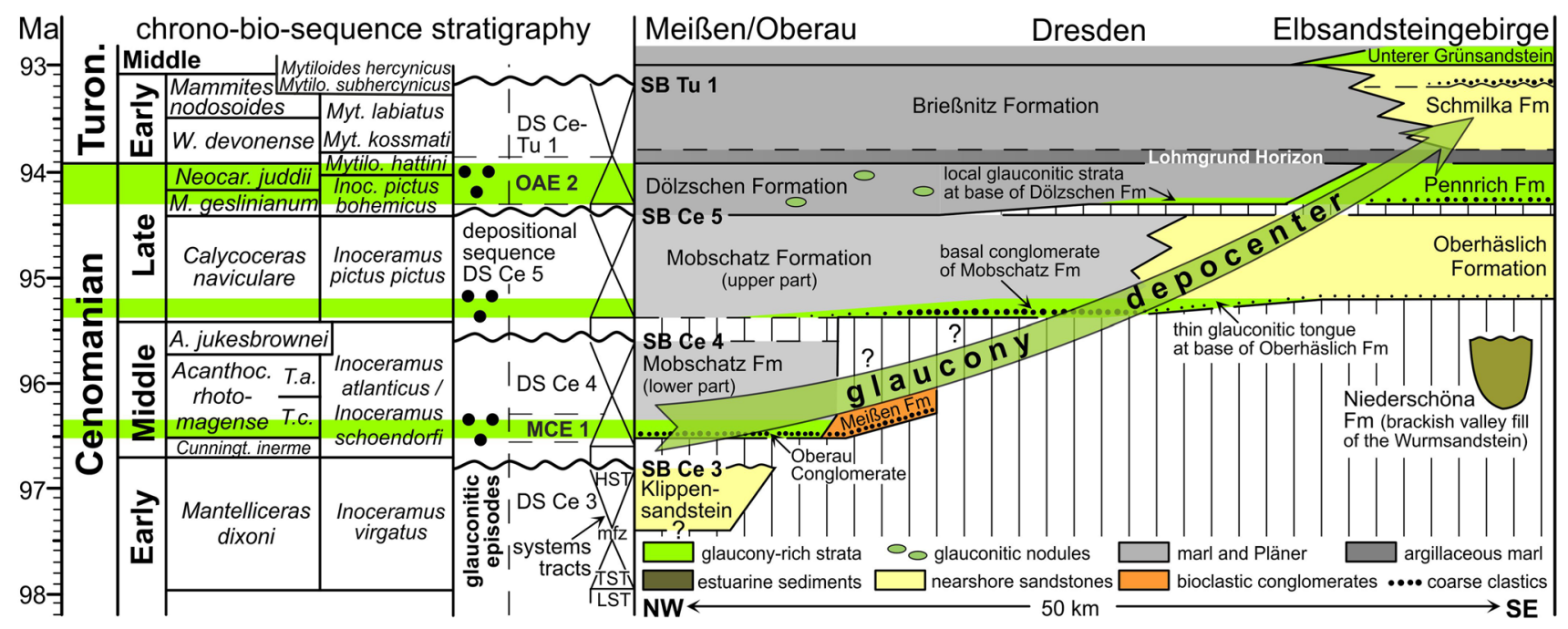

Fig. 10 Spatio-temporal distribution (Wheeler diagram) of glauconyrich strata in the Elbtal Group; note the onlap of the glauconitic facies zone following the course of the Cenomanian transgression and the correlation of glauconitic episodes to the (early) transgressive systems tracts of depositional sequences (see text for further explanation). $H S T$ highstand systems tract, $L S T$ lowstand systems tract, $M C E$

detrital clay minerals and carbonates provided the $\mathrm{Si}, \mathrm{Al}, \mathrm{Ca}$, $\mathrm{Mg}, \mathrm{K}$ and $\mathrm{Fe}$ ions that are required for the $\mathrm{Fe}(\mathrm{III})$-smectiteto-glauconite reaction (Baldermann et al. 2017). It is worth noting that even in this relatively condensed position on the Eastern Ore Mountains, where depositional sequence DS Ce 5 attains a thickness of only six metres, the maximum flooding zone is completely devoid of glaucony (Figs. 3c, d, 9), again suggesting that sediment starvation had little or no impact on the glauconitization process.

Locally developed, commonly thin glauconitic strata at the base of the upper Upper Cenomanian Dölzschen Formation correspond in lithofacies and sequence stratigraphic position to the ones found at the bases of the depositional sequences formed by the lower and upper Mobschatz Formation (DS Ce 4 and 5; Fig. 10). Tröger (1956) described the stratigraphic occurrence of glaucony in this stratigraphic interval from the Plauenscher Grund in Dresden, a submerged basement uplift, in considerable detail; the glaucony content reached its maximum in the basal conglomerate of the Dölzschen Formation, tracing the course of the plenus Transgression with its up-section decrease into the overlying Pläner strata. Of much greater interest is, however, the new observation of the massive development of glaucony in the Pennrich Formation, the proximal sandy equivalent of the Dölzschen Formation, at core Nasser Grund. Both formations constitute the latest Cenomanian TST of depositional sequence DS Ce-Tu 1 which culminated in a global earliest Turonian maximum flooding zone regionally reflected by the fine-grained marker bed of the Lohmgrund Horizon (e.g., Janetschke
Mid-Cenomanian (isotope) Event 1, $m f z$ maximum flooding zone, $O A E 2$ Oceanic Anoxic Event 2, TST transgressive systems tract, Turon. Turonian. Biostratigraphy, A. Acanthoceras; Cunningt. $=$ Cunningtoniceras, Inoc. Inoceramus, M. Metoicoceras, Myt./Mytilo. Mytiloides, Neocar. Neocardioceras, W. Watinoceras

and Wilmsen 2014; Wilmsen et al. 2019; Niebuhr et al. 2020), corresponding in stratigraphic position to maximum flooding surface K140 of Sharland et al. (2001) and the Cretaceous all-time peak in the curve of Haq (2014). At core Nasser Grund, the Pennrich Formation rests unconformably with a glauconitic basal conglomerate (GFT-1b) on the Oberhäslich Formation. Up-section, the formation consists of four stacked retro- to progradational sub-cycles (P1-P4) that form a high-frequency sequence, comprising ca. $405 \mathrm{kyr}$, that has also been identified in the Danubian Cretaceous Basin on the opposite side of the Mid-European Island (Richardt et al. 2013). The four cycles thus most likely correspond to short-eccentricity cycles (ca. $100 \mathrm{kyr}$ ) that have been identified in the corresponding stratigraphic interval of other sections ( $M$. geslinianum to $N$. juddii zones) by time series analyses of independent data sets (e.g., stable carbon isotopes: Voigt et al. 2008; Wendler et al. 2014). The four to five parasequences in each of the sub-cycles P1 to P4 (Fig. 4) are thus interpreted to reflect the precession signal (ca. $21 \mathrm{kyr}$ ) and their bundling into the sub-cycles P1-P4 the precession-eccentricity syndrome (PES, Fischer et al. 2004; see Gale et al. 1999 for Cenomanian examples), characteristic of low and mid latitudes, where obliquity is erratically identified (Berger and Loutre 1994; Kietzmann and Paulin 2019). Interestingly, only the lower and upper parts of the Pennrich Formation are strongly glauconitic while glaucony is rare in its middle part (Fig. 4), again reflecting the affiliation of glauconitic lithofacies to most proximal settings. The selective diagenetic alteration of 
glaucony grains in the upper part of cycle P3 below its terminal surface suggests subaerial exposure and concomitant oxidation of the green grains into iron hydroxides, supporting sea-level changes as a driver of sub-cycle formation. In general, the Pennrich Formation at Nasser Grund reflects a very shallow-marine, nearshore siliciclastic depositional system with tidal influences (e.g., tidal bundles), strong bioturbation, abundant argillaceous material, and common wood remains, indicating the vicinity of a densely vegetated land (i.e., the Westsudetic Island; Fig. 1b). According to Heimhofer et al. (2018), mid-latitudinal terrestrial plant ecosystems supported a rich and diverse flora during the Late Cenomanian to Early Turonian thermal maximum, and Niebuhr (2019) documented coastal lowlands with moisture-adapted vegetation for the early Late Cenomanian in Saxony. Geochemical data from the nearby Bohemian Cretaceous Basin foster the assumption of warm-humid conditions during the Late Cenomanian and the upper part of the Peruc-Korycany Formation is in places strongly glauconitic (Al-Bassam et al. 2019). The thickness of the Pennrich Formation $(60 \mathrm{~m})$ approximately corresponds to the accommodation generated during the latest Cenomanian (up to $50 \mathrm{~m}$ of eustatic sea-level rise: Voigt et al. 2006; Wilmsen et al. 2010; Richardt et al. 2013, plus regional subsidence), suggesting that the available space was constantly filled with sediment and the site Nasser Grund was possibly located close to a locus of fluvial input (the lithofacies does not support major longshore transport). It should be noted that the Pennrich Formation temporally corresponds to the latest Cenomanian segment of the oceanic anoxic event (OAE) 2 (Schlanger and Jenkyns 1976) and that there may be a genetic relationship between glauconitic episodes and oceanic anoxic events (cf. Föllmi 2016; Al-Bassam et al. 2019; Bansal et al. 2019). An important factor in this respect is an accelerated hydrological cycle due to an increase in temperature (cf. Larson and Erba 1999): Lithium isotope data require the riverine flux to increase approximately by two to four times during OAE 2 (Pogge von Strandmann et al. 2013). The warm and wet climatic conditions will promote chemical weathering and continental discharge to the ocean, considerably impacting marine biological, sedimentary and geochemical systems, preferentially in shallow-marine epeiric and peri-continental settings.

\section{Prerequisites for glaucony formation-myths and facts}

Glaucony formation (i.e., the syndepositional precipitation of $10-\AA$ glauconitic smectite and smectitic glauconite) allegedly depends on a number of environmental factors and occurs only in fairly deep marine settings (outer shelf to upper slope), under cool temperatures $\left(10-15^{\circ} \mathrm{C}\right)$, low accumulation rates and on long timescales $\left(10^{5}\right.$ to $10^{6}$ years for mature pellets; e.g., Odin and Matter 1981; Odin 1988; Odin and Fullagar 1988; Banerjee et al. 2016). We cannot comment much on the depositional temperatures in the Cenomanian of Saxony apart from the fact that the palaeo-latitudinal position of the Elbtal Group (ca. $40^{\circ} \mathrm{N}$; e.g., Vejbæk et al. 2010) and the biofacies (see comprehensive synopses in Niebuhr and Wilmsen 2014, 2016 as well as Föhlisch 1998 and Wilmsen 2017 for the Pennrich and Oberhäslich formations, respectively) suggest rather warm-temperate conditions (supported by the data from contemporaneous glauconitic strata in the Bohemian Cretaceous Basin; Al-Bassam et al. 2019). Furthermore, as outlined above in detail, the center of Cenomanian intrasequential glaucony formation and deposition in Saxony were shallow-water nearshore settings rather than the deeper offshore zone. Overall, the time-transgressive glaucony depocenter tracks the regional onlap patterns of the Elbtal Group, shifting southeast-wards during the Cenomanian 2nd-order sea-level rise (Fig. 10).

Another perception challenged by the observations from the Elbtal Group is the assumption of the long-term mode of formation of glaucony $\left(10^{5}\right.$ to $10^{6}$ years for mature pellets; e.g., Odin and Matter 1981). The temporal constraints of the sedimentary units of the lower Elbtal Group (Fig. 10) suggest that rather limited intervals of geological time are represented by the glaucony-bearing strata. The Oberau Conglomerate, for example, corresponds to the early Middle Cenomanian primus Event (Wilmsen et al. 2019) that forms an early transgressive marker bed in the lower A. rhotomagense ammonite zone, representing not more than 20 kyr (Gale 1995; Wilmsen 2007, 2012; Wilmsen et al. 2007). Also the relatively thick glauconitic succession in the lower and upper Pennrich Formation at core section Nasser Grund shows that not much time was needed for the glauconitization as the temporal framework (Fig. 10) indicates that only $400 \mathrm{kyr}$ were available for the deposition of the complete lithological unit. Accepting the four sub-cycles of the Pennrich Formation as an expression of the short eccentricity cycle (ca. $100 \mathrm{kyr}$ ), the temporal framework of glaucony formation can be narrowed down even more (e.g., the upper two glaucony-rich parasequences in cycle $\mathrm{P} 3$ will comprise less than $50 \mathrm{kyr}$ ). The glaucony development in the Pennrich Formation also wipes-out another myth on the prerequisites for glaucony formation, i.e., prevalent low accumulation rates. In the lower sub-cycle P1, where both matrix glaucony and small-grained glauconitic grains are common, the accumulation rate is $\sim 200 \mathrm{~m} / \mathrm{myr}(21 \mathrm{~m} / 100 \mathrm{kyr})$ which is a rather high value. Correspondingly, in the maximum flooding interval of the underlying depositional sequence DS Ce 5 for which lowered accumulation rates can be assumed at 
least for the siliciclastic Oberhäslich Formation, no glauconitization can be observed at all.

In a nutshell, the new stratigraphic, sedimentological, and mineralogical data from Saxony suggest that other factors than water depth, cool temperatures, long time scales, and sediment starvation promoted early Late Cretaceous glaucony formation.

\section{Conclusions}

The Cenomanian sedimentary strata of the Elbtal Group (Saxony, eastern Germany) reflect a major global sea-level rise and contain, in certain stratigraphic intervals, a green authigenic mineral in abundance. Based on detailed logging and sampling of new sections associated by careful stratigraphic-sedimentological, petrographical and mineralogical analyses, the environmental background and spatio-temporal patterns of glauconitic strata in Saxony are reconstructed and some general preconditions allegedly needed for glaucony formation are critically questioned.

Five new core sections of the lower Elbtal Group in Saxony were studied, following a transect from Meißen in the northwest to Bad Schandau in the southeast. The Middle-Upper Cenomanian succession comprises the marly Mobschatz and Dölzschen formations, reflecting the offshore facies zone of the Saxonian Cretaceous Basin, while the Oberhäslich and Pennrich formations represent contemporaneous nearshore environments. The XRD analyses of green grains extracted from selected samples revealed that the constituting green mineral is in any case glaucony, i.e., $10-\AA$ glauconitic mineral. Based on field observations as well as on the careful evaluation of litho- and microfacies, the Cenomanian glauconitic strata in Saxony have been grouped into 12 facies types, broadly reflecting a proximal-distal gradient. The glauconitic facies types (GFTs) contain granular and matrix glaucony that can be characterized as autochthonous to parautochthonous (i.e., intrasequential) in origin. When observed in a stratigraphic succession, GFT-1 to GFT12 commonly occur superimposed in transgressive cycles starting with the glauconitic basal conglomerates (GFT-1). Up-section, glauconitic sandstones and/or sandy glauconitites grading into bioturbated, marly glauconitic sandstone (GFT-2-7) follow. Fine-grained, bioturbated, argillaceous glauconitic sandstones, glauconitic argillaceous marls and marlstones, and glauconitic calcareous nodules (GFT-9 and -12) continue the retrogradational fining-upward trend; graded glauconitic tempestites (GFT-8) predominantly occur in the lower part of the transgressive cycles. The vertical facies succession with the upwards decreasing glaucony content clearly indicates that the center of production and deposition of glaucony in the Cenomanian of Saxony was the nearshore zone, contrasting to the deeper marine offshore modus of recent glaucony formation and highlighting the "dilemma of ancient nearshore glaucony". Overall, the time-transgressive glaucony depocenter tracks the regional onlap patterns of the Elbtal Group, shifting southeast-wards during the Cenomanian 2nd-order sea-level rise.

Furthermore, of great importance is the substantial development of glaucony in the uppermost Cenomanian Pennrich Formation, temporally corresponding to the Late Cenomanian interval of the oceanic anoxic event (OAE) 2. At the studied site, the formation reflects a shallow-marine, nearshore siliciclastic depositional system with tidal influences, abundant argillaceous material, and common wood remains, indicating the vicinity of a densely vegetated hinterland. The relatively large thickness $(60 \mathrm{~m})$ deposited in a relatively short period of time (ca. $400 \mathrm{kyr}$ ) signifies a constant filling of accommodation under wet, warm-temperate conditions. Temporal constraints based on sedimentary cycles reflecting the precession-eccentricity syndrome suggest that glaucony development occurred during the deposition of the Pennrich Formation despite high accumulation rates and on rather short-term time scales. Our new stratigraphic-sedimentological and mineralogical data thus indicate that environmental factors such as cool temperatures, great water depth, long time scales and sediment starvation had little or no impact on glaucony formation during the Cenomanian in Saxony, suggesting that the determining factors of early Late Cretaceous glaucony fundamentally differed from recent conditions and revealing certain limitations of the uniformitarian approach.

Acknowledgements We would like to express sincere thanks to K. Thalheim and J. Wazeck (both SNSD mineralogy section, Dresden) for professional support in XRD analyses. B. Gaitzsch (Freiberg) and K. Ullrich (Dresden) kindly provided access to the B14 and Nossener Brücke cores which are in the core repository of the TU Bergakademie Freiberg and the federal state capitol of Dresden, respectively. We are indebted to J. Richter, M. Lapp, F. Horna and C. Schulz (Federal State Geological Survey of Saxony, Freiberg) for granting access and providing any support during the study of the Nasser Grund core. We thank B. Niebuhr and M. Fengler (both Dresden) for stratigraphic discussions and hints to cryptic literature on glaucony from Saxony, respectively. We'd also like to thank T. Püttmann (Federal State Geological Survey of North-Rhine Westfalia, Krefeld) for stratigraphic evaluation of a few calcareous nannofossil samples from the B 14 and Nossener Brücke cores. Ronald Winkler (SNSD, Dresden) prepared the thin-sections with the usual care and precision. Financial support by the German Research Foundation (DFG, project code WI 1743/11-1) is gratefully acknowledged. We'd also like to thank two anonymous referees for their constructive comments which considerably improved the quality of the manuscript and A. Munnecke (Erlangen) for the editorial handling.

Funding Open Access funding enabled and organized by Projekt DEAL. 
Open Access This article is licensed under a Creative Commons Attribution 4.0 International License, which permits use, sharing, adaptation, distribution and reproduction in any medium or format, as long as you give appropriate credit to the original author(s) and the source, provide a link to the Creative Commons licence, and indicate if changes were made. The images or other third party material in this article are included in the article's Creative Commons licence, unless indicated otherwise in a credit line to the material. If material is not included in the article's Creative Commons licence and your intended use is not permitted by statutory regulation or exceeds the permitted use, you will need to obtain permission directly from the copyright holder. To view a copy of this licence, visit http://creativecommons.org/licenses/by/4.0/.

\section{References}

Al-Bassam K, Magna T, Vodrážka R, Čech S (2019) Mineralogy and geochemistry of marine glauconitic siliciclasts and phosphates in selected Cenomanian-Turonian units, Bohemian Cretaceous Basin, Czech Republic: implications for provenance and depositional environment. Geochemistry 79:347-368

Amorosi A (1995) Glaucony and sequence stratigraphy: a conceptual framework of distribution in siliciclastic sequences. J Sediment Res B65:419-425

Amorosi A (1997) Detecting compositional, spatial, and temporal attributes of glaucony: a tool for provenance research. Sediment Geol 109:135-153

Amorosi A, Sammartino I, Tateo F (2007) Evolution patterns of glaucony maturity: a mineralogical and geochemical approach. DeepSea Res Part II 54:1364-1374

Amorosi A, Guidi R, Mas R, Falanga E (2012) Glaucony from the Cretaceous of the Sierra de Guadarrama (Central Spain) and its application in a sequence-stratigraphic context. Int J Earth Sci 101:415-427

Baccelle L, Bosellini A (1965) Diagrammi per la stima visiva: della composizione percentuale nelle rocce sedimentarie, vol 1. Univ. degli studi, Ferrara

Baldermann A, Dietzel M, Mavromatis V, Mittermayr F, Warr LN, Wemmer K (2017) The role of Fe on the formation and diagenesis of interstratified glauconite-smectite and illite-smectite: A case study of Lower Cretaceous shallow-water carbonates. Chem Geol 453:21-34

Banerjee S, Chattoraj SL, Saraswati PK, Dasgupta S, Sarkar U, Bumby A (2012) The origin and maturation of lagoonal glauconites: a case study from the Oligocene Maniyara Fort Formation, western Kutch, India. Geol J 47:357-371

Banerjee S, Bansal U, Thorat A (2016) A review on palaeogeographic implications and temporal variation in glaucony composition. J Palaeogeogr 5:43-71

Bansal U, Pande K, Banerjee S, Nagendra R, Jagadeesan KC (2019) The timing of oceanic anoxic events in the Cretaceous succession of Cauvery Basin: constraints from ${ }^{40} \mathrm{Ar} /{ }^{39} \mathrm{Ar}$ ages of glauconite in the Karai Shale Formation. Geol J 54:308-315

Bansal U, Banerjee S, Pande K, Ruidas D (2020) Unusual seawater composition of the Late Cretaceous Tethys imprinted in glauconite of Narmada basin, central India. Geol Mag 157:233-247

Bansal U, Banerjee S, Ruidas DK, Pande K (2018) Origin and geochemical characterization of Maastrichtian glauconites in the Lameta Formation, Central India. J Palaeogeogr 7:99-116

Bärtling R (1920) Transgressionen, Regressionen und Faziesverteilung in der Mittleren und Oberen Kreide des Beckens von Münster. Z Dt Geol Ges 72:161-217
Beck R, Hazard J (1893) Erläuterungen zur geologischen Spezialkarte des Königreichs Sachsen, Nr. 66: Blatt Dresden. Königliches Finanzministerium, Leipzig

Berensmeier M, Dölling B, Linnert C, Wilmsen M (2018a) Stratigraphical dissection of proximal shallow-water deposits: integrated analysis of the Cenomanian-Coniacian in the southwestern Münsterland Cretaceous Basin (northwest Germany). Z dt Ges Geowiss 169:567-586

Berensmeier M, Dölling B, Frijia G, Wilmsen M (2018b) Facies analysis of proximal upper Cretaceous deposits in the southwestern Münsterland Cretaceous Basin (northwest Germany). Cretac Res 87:241-260

Berger A, Loutre MF (1994) Precession, eccentricity, obliquity, insolation and paleoclimates. In: Duplessy JC, Spyridakis M-T (eds), Long-term climatic variations. NATO ASI Subseries 1, 22, pp 107-151

Burnett JA (1998) Upper Cretaceous. In: Bown PR (ed) Calcareous nannofossil biostratigraphy. Chapman Hall, London, pp 132-199

Chafetz HS (2007) Paragenesis of the Morgan Creek Limestone, Late Cambrian, central Texas: constraints on the formation of glauconite. Deep-Sea Res II 54:1350-1363

Chafetz HS, Reid A (2000) Syndepositional shallow-water precipitation of glauconitic minerals. Sediment Geol 136:29-42

Dott RH (1964) Wacke, greywacke and matrix; what approach to immature sandstone classification? J Sediment Res 34:625-632

Dunham RJ (1962) Classification of carbonate rocks according to depositional texture. In: Ham WE(ed), Classification of carbonate rocks. Amer Assoc Petrol Geol, Mem 1:108-121

El Albani A, Meunier A, Fürsich FT (2005) Unusual occurrence of glauconite in a shallow lagoonal environment (Lower Cretaceous, northern Aquitaine Basin, SW France). Terra Nova $17: 537-544$

Fischer AG, D’Argenio B, Premoli Silva I, Weissert H, Ferreri V (2004) Cyclostratigraphic approach to earth's history: an introduction. In: D’Argenio B, Fischer AG, Premoli Silva I, Weissert H, Ferreri V (eds), Cyclostratigraphy: Approaches and case histories. SEPM Spec Publ 81:5-16

Fischer H (1990) Glauconite formation: discussion of the terms authigenic, perigenic, allogenic, and meta-allogenic. Eclogae Geol Helv 83:1-6

Föhlisch K (1998) Palökologie der sandig ausgebildeten Dölzschen Formation (Oberes Obercenoman) Sachsen. Abh Staatl Mus Min Geol Dresden 43(44):141-149

Föllmi KB (2016) Sedimentary condensation. Earth-Sci Rev 152:143-180

Funk H (1971) Zur Stratigraphie und lithologie des helvetischen kieselkalkes und der altmannschichten in der santis-churfirstengruppe (Nordostschweiz). Eclogae geol Helv 64:345-433

Gale AS (1995) Cyclostratigraphy and correlation of the Cenomanian stage in Western Europe. In: House MR, Gale AS (eds) Orbital forcing timescales and cyclostratigraphy. Geol Soc London Spec Publ 85:177-197

Gale AS, Young JR, Shackleton NJ, Crowhurst SJ, Wray DS (1999) Orbital tuning of Cenomanian marly chalk successions: towards a Milankovitch time-scale for the Late Cretaceous. Phil Trans Roy Soc London 357:1815-1829

Garzanti E (2019) Petrographic classification of sand and sandstone. Earth-Sci Rev 192:545-563

Geinitz HB (1850) Das Quadergebirge oder die Kreideformation in Sachsen, mit besonderer Berücksichtigung der glaukonitreichen Schichten. Weidmann'sche Buchhandlung, Leipzig

Goldring R (1999) Field palaeontology, 2nd edn. Longman, Singapore Hancock JM, Kauffman EG (1979) The great transgressions of the Late Cretaceous. J Geol Soc London 136:175-186 
Hancock JM (1989) Sea-level changes in the British region during the Late Cretaceous. Proc Geol Assoc 100:565-594

Haq BU (2014) Cretaceous eustasy revisited. Glob Planet Change 113:44-58

Haq BU, Hardenbol J, Vail P (1987) Chronology of fluctuating sea levels since the Triassic. Science 235:1156-1167

Harder H (1980) Syntheses of glauconite at surface temperatures. Clays Clay Miner 28:217-222

Harding SC, Nash BP, Petersen EU, Ekdale AA, Bradbury CD, Dyar MD (2014) Mineralogy and geochemistry of the Main Glauconite Bed in the Middle Eocene of Texas: Paleoenvironmental implications for the verdine facies. PLoS ONE 9:e87656

Heimhofer U, Wucherpfennig N, Adatte T, Schouten S, SchneebeliHermann E, Gardin S, Keller G, Kentsch S, Kujau A (2018) Vegetation response to exceptional global warmth during Oceanic Anoxic Event 2. Nature Commun 9:3832 (8 pp)

Hiss M (1982) Neue Ergebnisse zur Paläogeographie des Cenomans in Westfalen. N Jb Geol Paläont Monatsh 1982:533-546

Huggett JM (2005) Glauconites. In: Selley RC, Cocks LRM, Plimer IR (eds) Encyclopedia of Geology, vol 3. Elsevier, Amsterdam, pp 542-548

Huggett J, Adetunji J, Longstaffe F, Wray D (2017) Mineralogical and geochemical characterisation of warm-water, shallow-marine glaucony from the Tertiary of the London Basin. Clay Miner $52: 25-50$

Janetschke N, Wilmsen M (2014) Sequence stratigraphy of the lower Upper Cretaceous Elbtal Group (Cenomanian-Turonian of Saxony, Germany). Z Dt Gesr Geowiss 165:179-208

Janetschke N, Niebuhr B, Wilmsen M (2015) Inter-regional sequencestratigraphical synthesis of the Plänerkalk, Elbtal and Danubian Cretaceous groups (Germany): Cenomanian-Turonian correlations around the Mid-European Island. Cretac Res 56:530-549

Käßner A, Stanek KP, Lapp M (2020) Post-Variscan tectonic and landscape evolution of the Elbe Fault Zone and the Lusatian Block based on apatite fission-track data and geomorphologic constraints. Geomorphology 355:106860

Kietzmann DA, Paulin SM (2019) Cyclostratigraphy of an upper Valanginian-lower Hauterivian mixed siliciclastic-carbonate ramp succession (Pilmatué Member of the Agrio Formation), Loma La Torre section, northern Neuquén Basin, Argentina. Cretac Res 98:26-46

Kuhnt W, Holbourn A, Gale A, Chellai EH, Kennedy WJ (2009) Cenomanian sequence stratigraphy and sea-level fluctuations in the Tarfaya Basin (SW Morocco). Geol Soc Amer Bull 121:1695-1710

Larson RL, Erba E (1999) Onset of the mid-Cretaceous greenhouse in the Barremian-Aptian: Igneous events and the biological, sedimentary, and geochemical responses. Paleoceanography $14: 663-678$

López-Quirós A, Sánchez-Navas A, Nieto F, Escutia C (2020) New insights into the nature of glauconite. Amer Mineral 105:674-686

McRae SG (1972) Glauconite. Earth-Sci Rev 8:397-440

Meunier A, ElAlbani A (2007) The glauconite-Fe-illite-Fe-smectite problem: a critical review. Terra Nova 19:95-104

Myrow PM, Southard JB (1996) Tempestite deposition. J Sediment Res 66:875-887

Niebuhr B (2019) From animal to plant kingdom: the alleged sponge Siphonia bovista Geinitz from the Cretaceous of Saxony (Germany) in fact represents internal moulds of the cone-like plant fossil Dammarites albens Presl in Sternberg. Bull Geosci 94:221-234

Niebuhr B (2020) Pennrich-Formation. LithoLex - Lithostratigraphisches Lexikon Deutschland: https://litholex.bgr.de/ (downloaded 04/1172020)

Niebuhr B, Wilmsen M (2014) Kreide-Fossilien in Sachsen, Teil 1. Geol Saxon 60:1-254
Niebuhr B, Wilmsen M (2016) Kreide-Fossilien in Sachsen, Teil 2. Geol Saxon 62:1-245

Niebuhr B, Hiss M, Kaplan U, Tröger KA, Voigt S, Voigt T, Wiese F, Wilmsen M (2007) Lithostratigraphie der norddeutschen Oberkreide. SDGG 55:1-136

Niebuhr B, Wilmsen M, Voigt T (2020) Die Oberkreide (CenomaniumMittelconiacium) im Zittauer Sandsteingebirge (Deutschland, Tschechien). Z Dt Ges Geowiss 171:163-197

Odin GS (1988) Green marine clays. Develop Sediment 45: 446 pp, Elsevier, Amsterdam

Odin GS (1990) Clay mineral formation at the continent-ocean boundary: the verdine facies. Clay Miner 25:477-483

Odin GS, Matter A (1981) De glauconiarum origine. Sedimentology 28:611-641

Odin GS, Fullagar PD (1988) Geological significance of the glaucony facies. Develop Sediment 45:295-332

Odin GS, Sen Gupta BK (1988) Geological significance of the verdine facies. Develop Sediment 45:205-219

Odom IE (1976) Microstructure, mineralogy and chemistry of Cambrian glauconite pellets and glauconite, Central USA. Clay Clay Miner 24:232-238

Odom IE (1984) Glauconite and celadonite minerals. In: Bailey SW (ed), Micas. Rev Mineral Geochem 13: pp 554-572, Mineralogical Society of America, Washington

Petrascheck W (1902) Die Ammoniten der sächsischen Kreideformation. Beitr Paläont Geol Österr-Ungarns und des Orients 14:131162, pls 7-12

Pettijohn FJ, Potter PE, Siever R (1987) Sand and sandstone, 2nd edn. Springer, New York

Pogge von Strandmann PAE, Jenkyns HC, Woodfine RG (2013) Lithium isotope evidence for enhanced weathering during Oceanic Anoxic Event 2. Nature Geosci 6:668-672

Richardt N, Wilmsen M, Niebuhr B (2013) Late Cenomanian-Early Turonian facies development and sea-level changes in the Bodenwöhrer Senke (Danubian Cretaceous Group, Bavaria, Germany). Facies 59:803-827

Robaszynski F, Juignet P, Gale AS, Amédro F, Hardenbol J (1998) Sequence stratigraphy in the Cretaceous of the Anglo-Paris Basin, exemplified by the Cenomanian stage. In: Jaquin T, de Graciansky P, Hardenbol J (eds) Mesozoic and Cenozoic sequence stratigraphy of European basins. Soc Econ Palaeont Mineral Spec Publ 60:363-385

Schlanger SO, Jenkyns HC (1976) Cretaceous oceanic anoxic events: Causes and consequences. Geol Mijnb 55:179-184

Seibertz E (1977) Litho-, Bio-, Ökostratigraphie, Sedimentologie und Tektonik im Soester Grünsand. Geol Jb A40:61-113

Seifert A (1955) Stratigraphie und Paläogeographie des Cenoman und Turons im sächsischen Elbtalgebiet. Freib Forschungsh C14:1-218

Seilacher A, Aigner T (1991) Storm deposition at the bed, facies and basin scale: the geologic perspective. In: Einsele G, Ricken W, Seilacher A (eds) Cycles and Events in Stratigraphy. Springer, Berlin, pp 249-267

Sharland PR, Archer R, Casey DM, Davies RB, Hall SH, Heward AP, Horbury AD, Simmons MD (2001) Arabian Plate sequence stratigraphy. Geoarabia Spec Publ 2:1-371

Siegert T (1906) Section Kötzschenbroda-Oberau. Erl geol Specialk Königr Sachsen, B1 49 (2. Aufl), pp 1-64

Stow DAV (2005) Sedimentary rocks in the field. Manson Publishing, London

Tang D, Shi X, Ma J, Jiang G, Zhou X, Shi Q (2017) Formation of shallow-water glaucony in weakly oxygenated Precambrian ocean: an example from the Mesoproterozoic Tieling Formation in North China. Precambr Res 294:214-229

Thompson GR, Hower J (1975) The mineralogy of glauconite. Clays Clay Mineral 23:289-300 
Tröger K-A (1956) Über die Kreideablagerungen des Plauenschen Grundes (sedimentpetrographische und biostratinomischpaläontologische Untersuchungen). Jb Staatl Mus Mineral Geol Dresden 2:22-124

Tröger K-A (1967) Zur Paläontologie, Biostratigraphie und faziellen Ausbildung der unteren Oberkreide (Cenoman-Turon). Teil I - Paläontologie und Biostratigraphie der Inoceramen des Cenomans und Turons. Abh Staatl Mus Mineral Geol Dresden 12:13-207

Tröger K-A (1969) Zur Paläontologie, Biostratigraphie und faziellen Ausbildung der unteren Oberkreide (Cenoman-Turon). Teil II Stratigraphie und fazielle Ausbildung des Cenomans und Turons in Sachsen, dem nördlichen Harzvorland und dem Ohmgebirge. Abh Staatl Mus Mineral Geol Dresden 13:1-70

Tröger K-A (2015) Obercenomane Inoceramen aus der sächsischen Kreide. Geol Saxon 60:377-425

Tröger K-A, Niebuhr B (2014) Inoceramen. In: Niebuhr B, Wilmsen M (eds), Kreide-Fossilien in Sachsen, Teil 1. Geol Saxon 60:169-200

Udgata DBP (2007) Glauconite as an indicator of sequence stratigraphic packages in a Lower Paleocene passive-margin shelf succession, Central Alabama. Unpubl master thesis, 109 pp, Auburn University, Alabama.

Vejbæk OV, Andersen C, Dusa M, Herngreen W, Krabbe H, Leszczynski K, Lott GK, Mutterlose J, van der Molen AS (2010) Cretaceous. In: Doornenbal H, Stevenson A (eds) Petroleum Geological Atlas of the Southern Permian Basin Area. EAGE Publ, Houten, pp 195-209

Voigt S, Gale AS, Voigt T (2006) Sea-level changes, carbon cycling and palaeoclimate during the Late Cenomanian of northwest Europe; an integrated palaeoenvironmental analysis. Cretac Res 27:836-858

Voigt S, Erbacher J, Mutterlose J, Weiss W, Westerhold T, Wiese F, Wilmsen M, Wonik T (2008) The Cenomanian-Turonian of the Wunstorf section (North Germany): global stratigraphic reference section and new orbital time scale for Oceanic Anoxic Event 2. Newsl Stratigr 43:65-89

Voigt T (1994) Faziesentwicklung und Ablagerungssequenzen am Rand eines Epikontinentalmeeres - die Sedimentationsgeschichte der Sächsischen Kreide. Unpubl PhD thesis, 130pp, TU Bergakademie, Freiberg

Voigt T (1999) Ablagerungsbedingungen und Taphonomie der Schmilka-Formation (Unter-Turon) südlich von Pirna (Sächsisches Kreidebecken). Greifsw Geowiss Beitr 6:193-207
Voigt T (2009) Die Lausitz-Riesengebirgs-Antiklinalzone als kreidezeitliche Inversionsstruktur: geologische Hinweise aus den umgebenden Kreidebecken. Z geol Wissensch 37:15-39

Voigt T, Voigt S, Tröger K-A (1994) Faziesentwicklung einer ertrunkenen Felsküste-die obercenomane Monzonitklippe westlich von Dresden. Freib Forschungsh C452:23-34

Wendler JE, Meyers SR, Wendler I, Kuss J (2014) A million-year-scale control on Late Cretaceous sea-level. Newsl Stratigr 47:1-19

Wildberg H (1980) Glaukonitgenese und Lithofazies im Cenoman von Dortmund (Westfalen). N Jb Geol Paläont, Mh 1980:52-64

Wilmsen M (2003) Sequence stratigraphy and palaeoceanography of the Cenomanian Stage in northern Germany. Cretac Res 24:525-568

Wilmsen M (2007) Integrated stratigraphy of the upper Lower-lower Middle Cenomanian of northern Germany and southern England. Acta Geol Polon 57:263-279

Wilmsen M (2012) Origin and significance of Upper Cretaceous bioevents: Examples from the Cenomanian. Acta Palaeont Polon 57:759-771

Wilmsen M (2017) Macroinvertebrate fauna and depositional environment of the lower Upper Cenomanian Oberhäslich Formation in the Saxonian Cretaceous Basin (Germany). Ann Paléont 103:33-44

Wilmsen M, Niebuhr B, Hiss M (2005) The Cenomanian of northern Germany: facies analysis of a transgressive biosedimentary system. Facies 51:242-263

Wilmsen M, Niebuhr B, Wood CJ, Zawischa D (2007) Fauna and palaeoecology of the Middle Cenomanian Praeactinocamax primus Event at the type locality, Wunstorf quarry, northern Germany. Cretac Res 28:428-460

Wilmsen M, Niebuhr B, Chellouche P, Pürner T, Kling M (2010) Facies pattern and sea-level dynamics of the early Late Cretaceous transgression: a case study from the lower Danubian Cretaceous Group (Bavaria, southern Germany). Facies 56:483-507

Wilmsen M, Vodrážka R, Niebuhr B (2011) The Upper Cenomanian and Lower Turonian of Lockwitz (Dresden area, Saxony, Germany): lithofacies, stratigraphy and fauna of a transgressive succession. Freib Forschungsh C 540:27-45

Wilmsen M, Niebuhr B, Fengler M, Püttmann T, Berensmeier M (2019) The Late Cretaceous transgression in the Saxonian Cretaceous Basin (Germany): old story, new data and novel findings. Bull Geosci 94:71-100 